\title{
Employing contact metamorphism to assess the conditions of pluton emplacement and timing of recrystallization in southwestern Kellys Mountain, Cape Breton Island, Nova Scotia
}

\begin{tabular}{|r|l|}
\hline Journal: & Canadian Journal of Earth Sciences \\
\hline Manuscript ID & cjes-2017-0052.R2 \\
\hline Manuscript Type: & Article \\
\hline Date Submitted by the Author: & 30 -Jun-2017 \\
\hline Complete List of Authors: & $\begin{array}{l}\text { Shawwa, Nabil; Acadia University, Earth and Environmental Science } \\
\text { Raeside, Rob; Acadia University, Earth and Environmental Sciences } \\
\text { McMullin, David; Acadia University, Earth and Environmental Science } \\
\text { McFarlane, Christopher; University of New Brunswick, Department of Earth } \\
\text { Sciences }\end{array}$ \\
\hline $\begin{array}{r}\text { Is the invited manuscript for } \\
\text { consideration in a Special } \\
\text { Issue? : }\end{array}$ & N/A \\
\hline Keyword: & contact metamorphism, bras d'or terrane, pluton emplacement \\
\hline \multicolumn{2}{|c}{} \\
\hline
\end{tabular}

\section{SCHOLARONE \\ Manuscripts}


1 Employing contact metamorphism to assess the conditions of pluton emplacement

2 and timing of recrystallization in southwestern Kellys Mountain, Cape Breton

4

5

6 Nabil A. Shawwa ${ }^{1}$, Robert P. Raeside ${ }^{1 *}$, David W.A. McMullin ${ }^{1}$, and Christopher R.M.

$$
\text { McFarlane }{ }^{2}
$$

8

9 1. Department of Earth and Environmental Science, Acadia University, Wolfville, Nova Scotia B4P 2R6, Canada

2. Department of Earth Sciences, University of New Brunswick, Fredericton, New 
Abstract

At Kellys Mountain, Cape Breton Island, Nova Scotia, the late Neoproterozoic

17 Glen Tosh formation (a low-grade metapsammite-metapelite unit of the George River

18 Metamorphic Suite) has been intruded by diorite, granodiorite and granite plutons, and

19 the diorite hosts a narrow contact metamorphic aureole. New mapping and sampling in

20 the contact aureole reveals that the metasedimentary rocks have reached amphibolite-

21 facies metamorphism resulting in the development of neoformed biotite, muscovite,

22 cordierite, ilmenite, garnet, andalusite, sillimanite, monazite, and spinel within the meta-

23 pelite, a mineral assemblage also found in the Kellys Mountain Gneiss as a result of low-

24 pressure regional metamorphism. Neoformed minerals and the disappearance of foliation

25 defines a contact metamorphic aureole within $300 \mathrm{~m}$ of the pluton contacts.

Petrographic and microprobe analyses of equilibrium assemblages in metapelitic

27 units of the contact aureole yielded metamorphic pressures of $250 \mathrm{MPa}$, implying an

28 intrusion depth of ca. $9 \mathrm{~km}$, with temperatures ranging from 365 to $590^{\circ} \mathrm{C}$. The presence

29 of earlier-formed andalusite and garnet indicates the rocks may have initially undergone a

30 low-pressure regional metamorphic event prior to contact metamorphism. Monazite in

31 the contact aureole was dated using in-situ $\mathrm{U}-\mathrm{Pb}$ methods and yielded an age of $480.9 \pm$

32 $3.7 \mathrm{Ma}$, interpreted as the time of formation of the contact metamorphic aureole. 


\section{Résumé}

Au mont Kellys, île du Cap-Breton, Nouvelle-Écosse, le Néoprotérozoïque tardif

57 événement de métamorphisme de contact. La monazite dans l'auréole de contact a été

58 datée in situ en utilisant les méthodes de ${ }^{207} \mathrm{~Pb} /{ }^{235} \mathrm{U}$. Les résultats indiquent que la

59 recristallisation du métamorphisme de contact est datée de 480,9 $\pm 3,7 \mathrm{Ma}$, ce qui est

60 interprété comme le temps de formation de l'auréole métamorphique. 
62 Keywords: contact metamorphism, Bras d'Or terrane, pluton emplacement 63 


\section{Introduction}

Kellys Mountain lies in Cape Breton Island, a geologically complex area of the northern Appalachian Orogen, and the site of deformation, regional metamorphism and plutonism associated with terrane amalgamation. Barr and Raeside (1989) identified portions of three terranes and a cryptic Grenvillian inlier (Blair River Inlier) in Cape Breton Island. Kellys Mountain is situated in the Bras d'Or terrane, which is located mainly in central Cape Breton Island between the Aspy terrane to the northwest and the Avalonian Mira terrane to the southeast (Fig. 1) (Barr and Raeside 1989).

The Bras d'Or terrane is a suspect terrane that extends to the northeast where it has been correlated to rocks in southern Newfoundland and similar units also exist in southern New Brunswick in the Brookville terrane (Barr and Raeside 1989, White and Barr 1996, Barr et al. 1998). It is largely composed of late Neoproterozoic to Paleozoic units, defined by Raeside and Barr (1990) as: (i) the Bras d'Or Metamorphic Suite; (ii) Neoproterozoic generally low-grade metamorphic rocks; (iii) Late Neoproterozoic to Cambrian supra-subduction zone intrusive units; and (iv) younger intrusive units (Fig. 1).

The two metamorphic components, the high-grade Bras d'Or Metamorphic Suite and the low-grade metamorphic rocks are jointly referred to as the George River Metamorphic Suite. Together, these components make up the outboard margin of Ganderia (Hibbard et al. 2006) and the metamorphic units have been correlated regionally to the Brookville Gneiss and Green Head Group of the Brookville terrane of southern New Brunswick (Barr et al. 2013).

Kellys Mountain is a microcosm of the Bras d'Or terrane, displaying elements of all four of the defining components of the terrane. The Bras d'Or Metamorphic Suite is 
87 represented by the Kellys Mountain Gneiss, which was studied by Jamieson (1984) to

88 determine the peak metamorphic conditions. Field relations, petrology, and geochemistry

89 of the diorite and leucogranite plutons, elements of the two plutonic components of the

90 Bras d'Or terrane, were investigated by Barr et al. (1982) to discern the affinities of the

91 granitoid bodies. The metapelitic and meta-semipelitic rocks of Kellys Mountain are part

92 of the generally low-grade metamorphic component and have not previously been studied

93 in detail. They have been informally assigned to the Glen Tosh formation in a

94 complementary study by Barr et al. (2013) who provided whole-rock chemical and $\mathrm{Nd}$

95 isotopic analyses to compare the Glen Tosh formation with the Kellys Mountain Gneiss.

96 That study indicated that the two units are compositionally, chemically and isotopically

97 similar, and that the detrital components of both units were derived from the same or

98 similar sources, likely an eroding active continental margin containing 2 Ga and Late

99 Neoproterozoic components.

100 The main purposes of this study are to determine the depth of intrusion of the

101 pluton(s) responsible for the contact metamorphic aureole, as indicated by the conditions

102 of metamorphism in the contact aureole, to ascertain the degree to which the pluton(s)

103 is/are agent(s) of metamorphism, and to determine the timing of the events. With

104 improved understanding of the nature and timing of metamorphism, it will be possible to

105 evaluate if the proposed correlation (Barr et al. 2013) of the Neoproterozoic Glen Tosh

106 formation with the Kellys Mountain Gneiss is viable, and speculate more rigorously on

107 its significance for the other metamorphic components of the Bras d'Or terrane. This

108 study also addresses the question why the regional metamorphism of the Glen Tosh 
109 formation in general is of much lower grade than the Kellys Mountain Gneiss and

110 whether they record the same or different metamorphic events.

\section{Geology of Kellys Mountain}

Kellys Mountain (Fig. 2) is typical of the Bras d'Or terrane, being underlain by all

114 four of its constituent elements (Raeside and Barr 1992). Two of these components are 115 represented by metamorphic units, both of which are intruded by plutons (the two

116 intrusive components of the Bras d'Or terrane) and both of which display evidence for

117 having undergone two metamorphic events. The Bras d'Or Metamorphic Suite in this

118 area is represented by the Kellys Mountain Gneiss (Fig. 2), in which the age of the

119 metamorphism has been determined by $\mathrm{U}-\mathrm{Pb}$ dating techniques to be $515 \pm 1 \mathrm{Ma}$ from

120 monazite in cordierite-bearing migmatite (Keppie et al. 1998) and $496 \pm 5 \mathrm{Ma}$ from

121 titanite in amphibolite (Dunning et al. 1990). The Kellys Mountain Granite (Barr et al.

122 2013), formerly referred to as the Kellys Mountain leucogranite, intruded the Kellys

123 Mountain Gneiss on its southwest side (Fig. 2) (Barr et al. 1982) and has been dated at

$124498 \pm 2 \mathrm{Ma}$ using U-Pb isotopic methods on zircon (Barr et al. 1990). The Kellys

125 Mountain Gneiss is also in contact with dioritic rocks and with outlying granitic bodies

126 that have been correlated with the Kellys Mountain Granite (Jamieson 1984; Fig. 2).

127 Jamieson (1984) identified four lithological components of the Kellys Mountain

128 Gneiss: biotite gneiss, cordierite-biotite gneiss, migmatitic cordierite-aluminosilicate

129 gneiss, and amphibolite. Metamorphic petrology, AFM projections of coexisting phases,

130 and mineral analysis were done by Jamieson (1984) to determine the peak metamorphic

131 conditions of the Kellys Mountain Gneiss, estimated to be at 100-350 MPa and 580- 
$132700^{\circ} \mathrm{C}$. Jamieson (1984) established the upper limits of these conditions based on good 133 preservation of the reaction:

$$
\mathrm{Bt}+\mathrm{And}+\mathrm{Qtz}=\mathrm{Crd}+\mathrm{Kfs}+\mathrm{Sil}+\mathrm{Ilm}+\text { water }
$$

135 (mineral abbreviations throughout this paper follow the recommendations of Fettes and 136 Desmons, 2007).

137 Low-grade metamorphic rocks are found in the southwestern end of Kellys 138 Mountain (Fig. 2) and have been informally referred to as the Glen Tosh formation (Barr 139 et al. 2013). The unit can be traced to the north into the Cape Breton Highlands (Fig. 2), 140 where metamorphic grade gradually increases to upper amphibolite facies, and where the 141 unit has been termed the Barachois River Metamorphic Suite (Fig. 1; Raeside and Barr 142 1992). The Glen Tosh formation is composed mainly of metamorphosed quartz wacke, 143 also described as metasiltstone and metagreywacke by Barr et al. (1982) and is similar to 144 other low-grade metapelitic units across the Bras d'Or terrane (Blues Brook Formation in 145 the Creignish Hills, Malagawatch Formation in the North Mountain, Benacadie Brook 146 Formation in Boisdale Hills, McMillan Flowage Formation in the eastern Cape Breton 147 Highlands), which are collectively termed the Georges River Metamorphic Suite (Barr et 148 al. 2013). The semipelitic and pelitic rocks of the Glen Tosh formation were intruded by 149 the same dioritic and granitic units as was the Kellys Mountain Gneiss.

150 Throughout southwestern Kellys Mountain the Glen Tosh formation mainly 151 consists of meta-quartz wacke, with scattered pods of andesitic meta-tuff and more 152 micaceous phyllite. For the most part, outcrops of the Glen Tosh formation are grey, very 153 fine grained rocks with a weak foliation. More pelitic rocks are phyllite, with a more 154 pronounced muscovite-dominated foliation, oriented biotite and local large cordierite 
155 knots, up to $3 \mathrm{~cm}$ across (Fig 3A). More siliceous rocks are more massive and display

156 less obvious foliation in outcrop, however the presence of a weak foliation, even in

157 psammitic rocks is an indicator that the unit underwent regional metamorphism prior to

158 contact metamorphism. Immediately adjacent to the plutonic rocks in central Kellys

159 Mountain, the meta-quartz wacke lacks foliation and displays a hornfelsic texture in

160 which the muscovite and biotite do not exhibit a preferred orientation and neo-formed

161 cordierite ranges up to $0.2 \mathrm{~mm}$ in diameter (Fig. 3B).

162 Metapelitic and metapsammitic rocks consist primarily of quartz and plagioclase,

163 with significant detrital K-feldspar, biotite, muscovite, and opaque minerals in most

164 samples (Table 1). Garnet occurs sparsely throughout the metapelite unit. Cordierite and

165 andalusite were found in some samples located within the contact aureole, and

166 porphyroblastic cordierite occurs in scattered localities throughout the Glen Tosh

167 formation. Sillimanite and spinel were identified in one sample of hornfels (NS-030),

168 within $50 \mathrm{~m}$ of the igneous contact (Fig 3C). The zone of hornfels extends up to $300 \mathrm{~m}$

169 from the plutonic contact. Retrograde chlorite, secondary muscovite, sericite, and pinite

170 after cordierite were all observed as alteration products. Accessory apatite, titanite, rutile,

171 zircon, monazite, and xenotime also occur in these rocks.

172 Although both the Kellys Mountain Gneiss and the Glen Tosh formation exhibit

173 regional metamorphic fabrics, metamorphism in the Glen Tosh formation occurred at

174 lower grade, with most assemblages exhibiting greenschist-facies mineralogy, except for

175 a few local reports of andalusite and cordierite (Barr et al. 2013). In the aureole, the

176 metamorphic conditions are typical of contact metamorphism based on the presence of

177 co-existing cordierite and sillimanite, and the decussate textures in semipelitic lithologies. 
179 affected by regional metamorphic and deformational events, which is evident from the

180 foliation developed in them. However, the Glen Tosh formation metamorphism occurred

181 at a much lower grade, as it has developed only low-grade greenschist-facies

182 assemblages, although cordierite and andalusite have been reported in some localities

183 (Barr et al. 2013).

The recognition of the Kellys Mountain Gneiss and the Glen Tosh formation (and

185 by extension the Barachois River Metamorphic Suite) as parts of the two metamorphic

186 components of the Bras d'Or terrane is not without difficulty. A similar situation exists

187 between the Brookville Gneiss and the Green Head Group in the Brookville terrane of

188 southern New Brunswick (White and Barr 1996, Barr et al. 2014). The Kellys Mountain

189 Gneiss was assigned to the regional low-pressure, high-grade gneiss component on the

190 basis of cordierite- and sillimanite-bearing assemblages and widespread gneissic

191 foliation, but the unit lacks the marble and calc-silicate lithologies typical of other blocks

192 of gneiss in the Bras d'Or terrane, e.g., Lime Hill Gneissic Complex, Frenchvale Road

193 Metamorphic Suite, Skye Mountain Metamorphic Suite (Fig. 2). The similar lithological

194 composition (although very different grade of metamorphism) between the Kellys

195 Mountain Gneiss and the Glen Tosh formation (Table 1) led Barr et al. (2013) to

196 investigate the whole-rock chemistry and Sm-Nd isotopic characteristics of both units,

197 wherein their similarity was validated.

198 Both the Kellys Mountain Granite and the Kellys Mountain dioritic rocks are in

199 contact with the Glen Tosh formation (Fig. 4A). Xenoliths derived from the Glen Tosh

200 formation were observed within diorite providing firm evidence for the later intrusion of 
201 the diorite. Several attempts to map the plutonic rocks in Kellys Mountain (Barr et al.

202 1982, Barr et al. 1992) were summarized by Barr et al. (2013). The granitic and dioritic

203 rocks are irregularly distributed throughout southwestern Kellys Mountain, east of the

204 Glen Tosh formation, indicating the two units are closely associated and may be co-

205 magmatic (Barr et al. 2013). Leucogranitic dykes of the Kellys Mountain Granite were

206 found within the diorite providing evidence that intrusion of the granite was at least in

207 part after the emplacement of the diorite (Fig. 4B). Most recently Barr et al. (2013)

208 combined the various granitic components of Kellys Mountain into one pluton named the

209 Kellys Mountain Granite, and described it as consisting of leucogranite, syenogranite,

210 monzogranite and granodiorite. The Kellys Mountain dioritic rocks are more varied in

211 composition and include diorite, quartz diorite, tonalite, granodiorite, quartz monzonite,

212 and hornblendite (Barr et al. 2013).

213

\section{Petrography}

215 In thin section, the rocks of the Glen Tosh formation are very fine-grained and

216 moderately homogeneous. In some areas, the unit is well bedded and foliated, but

217 elsewhere it is more psammitic, lacks oriented mica, and appears granoblastic.

218 Sedimentary laminations are commonly well preserved and cross-bedding has been

219 observed. Biotite is for the most part aligned parallel to bedding and primary muscovite

220 typically also appears as aligned grains, in some places in biotite-rich layers. In most

221 samples within the contact aureole, cordierite is present as large poikiloblasts composed

222 of aggregates of several grains and parts of the adjacent matrix. Scarce garnet is generally

223 altered, but where well-preserved is highly variable in $\mathrm{Ca}, \mathrm{Mn}, \mathrm{Mg}$ and $\mathrm{Fe}$ content 
224 (Shawwa 2013). Sillimanite is found interlocking between quartz grains (Fig. 3C). Biotite

225 is found overgrowing andalusite (Fig. 3D); and in one sample, cordierite overgrows

226 andalusite. The opaque minerals are ilmenite, magnetite, and hematite. Trace amounts of

227 zircon, monazite and xenotime are also present.

228 The quartz-rich rocks of the Glen Tosh formation are only slightly altered. In

229 some cases, the cordierite has been altered to pinite, and garnet has been altered to

230 chlorite. Meta-tuff tends to display more extensive alteration with the development of

231 sericite after feldspar, and chlorite after actinolite, although some chlorite is also

232 prograde. In adjacent granite, the main form of alteration is sericitization of feldspar.

234 Mineral Chemistry

235 Overview

236 Eight samples were selected for analysis of coexisting plagioclase, K-feldspar,

237 biotite, muscovite, cordierite, garnet and ilmenite, where available, using the JEOL JXA-

2388200 Superprobe in the Robert M. MacKay Laboratory of the Dalhousie Regional

239 Electron Microprobe Facility. Quantitative WDA was done using an accelerating voltage

240 of $15 \mathrm{kV}$, beam current of $20 \mathrm{nA}$, typical beam diameter of $1 \mu \mathrm{m}$, peak count time of $20 \mathrm{~s}$

241 and background count time of 10 s. Standards employed were sanidine (K), Cr-metal

242 (Cr), jadeite (Na), Garnet12442 (Al, Fe, Si), pyrolusite (Mn) and Kanganui kaersutite

$243(\mathrm{Ca}, \mathrm{Ti}, \mathrm{Mg})$. For thermodynamic calculations, the aluminosilicate minerals are assumed

244 to be pure and grains were not analyzed by electron microprobe. All calculations were

245 done assuming the iron is $\mathrm{Fe}^{2+}$. 
Mineral assemblages were further assessed using petrographic studies and phase

247 relation diagrams to determine which reactions have occurred prior to determination of

248 the pressures and temperatures of metamorphism using the TWQ software (Berman,

249 2007). Representative analyses are presented in Table 2; full details of all analyses were

250 presented by Shawwa (2013).

Glen Tosh formation

Plagioclase in the Glen Tosh formation at a distance from the contact

254 metamorphic aureole vary from $\mathrm{An}_{22}$ to $\mathrm{An}_{31}$ (e.g. DM-14 and RR-202). Low

255 metamorphic grade rocks closer to the contact aureole also have constant but elevated

256 compositions of $\mathrm{An}_{34}$ to $\mathrm{An}_{38}$ (e.g. NS-032). Lower grade contact metamorphic rocks in

257 the contact aureole, but distant from the contact are highly variable in composition,

258 ranging from $\mathrm{An}_{22}$ to $\mathrm{An}_{45}$ in a single rock (NS-30). The grains with the highest An

259 contents may represent detrital grains derived from different sources. Closer to the

260 contact, higher grade rocks have relatively constant compositions of $\mathrm{An}_{25}$ to $\mathrm{An}_{27}$ (e.g.

261 NS-028). No compositional zoning was detected in plagioclase. K-feldspar ranges from

$262 \mathrm{Or}_{91}$ to $\mathrm{Or}_{99}$ in very low grade rocks to $\mathrm{Or}_{80}$ to $\mathrm{Or}_{96}$ nearer the contact.

263 Biotite compositions are uniform within samples, but appear to vary with grade.

264 The lowest grade biotite has the lowest $\mathrm{FeO}$ and $\mathrm{TiO}_{2}$ contents. Muscovite $\mathrm{Na} /(\mathrm{Na}+\mathrm{K}+$

$265 \mathrm{Ca}$ ) ratios decrease from the regionally metamorphosed rocks into the aureole.

266 Garnet (Fig. 5A) is present in only two of the analyzed samples. In sample RR-

267202 it is unzoned, as shown by back-scattered electron imaging (Fig. 5B) and WDA

268 analysis, with $\mathrm{Alm}_{54} \mathrm{Sps}_{29} \operatorname{Prp}_{10} \mathrm{Grs}_{7}$. In sample DM91-14 it is mildly zoned from 
$269 \mathrm{Alm}_{37} \mathrm{Sps}_{39} \operatorname{Prp}_{10} \mathrm{Grs}_{14}$ (core) to $\mathrm{Alm}_{43} \operatorname{Sps}_{37} \operatorname{Prp}_{12} \mathrm{Grs}_{7}$ (rim). Almandine content varies

270 inversely with spessartine and grossular content.

271 Cordierite in the rocks of the contact metamorphic aureole (Fig 5B) ranges in

$272 \mathrm{Mg} /(\mathrm{Mg}+\mathrm{Fe})$ ratio from 0.60 to 0.72 and is uniform within samples in the contact

273 aureole. Andalusite and sillimanite, $\mathrm{Al}_{2} \mathrm{SiO}_{5}$, were both observed in the Glen Tosh

274 formation (Table 1). The average $(\mathrm{Fe}+\mathrm{Mn}) /(\mathrm{Fe}+\mathrm{Ti}+\mathrm{Mn})$ ratio in ilmenite indicates it

275 conforms closely to the ideal formula $(\mathrm{Fe}, \mathrm{Mn}) \mathrm{TiO}_{3}$, with up to $17 \% \mathrm{MnTiO}_{3}$ component.

276

277 Kellys Mountain Gneiss

278 For comparative purposes, and to distinguish the contact metamorphism from the

279 regional metamorphism at Kellys Mountain, mineral analyses were also obtained by

280 electron microprobe for a sample (NS-026) of the Kellys Mountain Gneiss. Plagioclase,

281 K-feldspar, biotite, cordierite, and ilmenite were analyzed (Table 2). Jamieson (1984)

282 also reported mineral analyses for plagioclase, K-feldspar, cordierite, biotite, oxides,

283 aluminosilicate minerals, and retrograde phases.

284 As in some of the higher grade rocks of the Glen Tosh formation, plagioclase in

285 the Kellys Mountain Gneiss sample has low and uniform anorthite contents of $\mathrm{An}_{22}$ to

$286 \mathrm{An}_{26}$, comparable to values of $\mathrm{An}_{22}$ to $\mathrm{An}_{30}$ reported by Jamieson (1984). K-feldspar in

287 the Kellys Mountain Gneiss has lower and variable orthoclase contents of Or $_{81}$ to Or $_{94}$

288 similar to the higher grade samples of the Glen Tosh formation, and to the results

289 reported by Jamieson (1984), which vary from $\mathrm{Or}_{77}$ to $\mathrm{Or}_{95}$.

290 The compositions of both biotite and cordierite from the Kellys Mountain Gneiss

291 sample are also similar to the compositions of these phases in higher grade rocks of the 
292 Glen Tosh formation with a Fe/(Fe+Mg) ratio ranging from 0.46 to 0.54 (Table 2), almost 293 identical to that reported by Jamieson (1984). Titanium content in the biotite from the 294 Kellys Mountain Gneiss is also similar to the higher grade samples of the Glen Tosh 295 formation. As also reported by Jamieson (1984), ilmenite in the Kellys Mountain Gneiss 297 departs from the ideal formula, suggesting a ferric iron (hematite) component in solid 298 solution between $\left(\mathrm{Fe}^{2+} \mathrm{Mn}\right) \mathrm{TiO}_{3}$ and $\mathrm{Fe}_{2} \mathrm{O}_{3}$.

300 Metamorphic Conditions

301 KFMASH Relationships

302 Univariant metamorphic reactions in the model pelitic system KFMASH are 303 shown in Fig. 6, as used for the Ballachulish contact aureole by Pattison and Harte 304 (1985). The reactions delimit the pressure and temperature conditions in the Glen Tosh 305 formation based on the mineral assemblages. The temperature of metamorphism can also 306 be determined for the Kellys Mountain Gneiss sample, which can be compared to results 307 of Jamieson (1984).

308 The plot on Fig. 6 incorporates the P-T conditions that would be encountered in 309 high-heat flow metamorphism. In the Glen Tosh formation, an upper limit for 310 temperature is the appearance of melt, which is nowhere found as a separate component 311 in the aureole.

312 The mineral assemblage of sample NS-030 (see Fig. 2 for location) includes 313 quartz-biotite-cordierite-sillimanite-spinel-K-feldspar, and therefore is constrained to 314 lie on the univariant line of reaction (Fig. 6) 


$$
\mathrm{Qtz}+\mathrm{Fe}-\mathrm{Bt}+\mathrm{Als}=\mathrm{Fe}-\mathrm{Crd}+\mathrm{Kfs}+\mathrm{H}_{2} \mathrm{O}
$$

316 Recognizing limitations involving the understanding of iron-magnesium solid solution in 317 cordierite (Martignole and Sisi 1981; Bhattarcharya 1986), the pressure and temperature

318 conditions of this reaction line are poorly constrained. Based on the presence of

319 sillimanite, the reaction is limited to the high temperature side of the And = Sil reaction

320 line. Also for reaction (1), the pressure and temperature conditions are limited by the

321 absence of silicate melt (L) in the reaction (Fig. 6),

$$
\mathrm{Pl}+\mathrm{Kfs}+\mathrm{Qtz}+\mathrm{H}_{2} \mathrm{O}=\mathrm{L}
$$

323 This constrains the pressure and temperature of sample NS-030 to the range of 200 to 230 $324 \mathrm{MPa}$ at 630 to $675^{\circ} \mathrm{C}$.

325 Sample NS-032 (see Fig. 2 for location) consists of the equilibrium assemblage 326 quartz-biotite-cordierite-andalusite-K-feldspar. The pressure and temperature conditions 327 of this sample can also be constrained to lie on the univariant line, reaction (1). However, 328 based on the presence of andalusite, it is limited to the lower temperature side of the And $329=$ Sil reaction line. Reaction (1) plots in the divariant field of Mg-chlorite breaking down 330 to biotite and cordierite, which is represented by (Fig. 6)

$$
\mathrm{Qtz}+\mathrm{Ms}+\mathrm{Mg}-\mathrm{Chl}=\mathrm{Bt}+\mathrm{Crd}
$$

332 This indicates that sample NS-032 crystallized at a pressure ranging up to $200 \mathrm{MPa}$ and 333 temperature up to $630^{\circ} \mathrm{C}$.

334 Sample DM-14 (see Fig. 2 for location) consists of the assemblage quartz-biotite335 muscovite-K-feldspar, and it is therefore not a good indicator of pressure, but does 336 indicate a possible temperature range. Based on the absence of silicate melt, the upper 
337 temperature is limited by reaction (2). The temperature is also limited by the divariant 338 reaction $($ Fig. 6)

$$
\mathrm{Qtz}+\mathrm{Mg}-\mathrm{Bt}+\mathrm{Ms}=\mathrm{Kfs}+\mathrm{Mg}-\mathrm{Crd}+\mathrm{H}_{2} \mathrm{O}
$$

340 The absence of cordierite in this sample suggests that it equilibrated on the low

341 temperature side of reaction (4). Reactions (2) and (4) intersect at $655^{\circ} \mathrm{C}$, thereby

342 indicating the maximum temperatures sample DM-14 could have reached during

343 metamorphism, but the actual conditions cannot be constrained beyond the divariant field

344 bounded by these two reactions.

345 Sample RR-202 (see Fig. 2 for location) consists of the assemblage quartz-

346 plagioclase-K-feldspar-muscovite-biotite-cordierite, and like sample DM-14, it is also a 347 much better indicator of temperature than of pressure. It too is limited by reactions (2) 348 and (4) indicating it has reached maximum temperatures of $655^{\circ} \mathrm{C}$. The lower limit of 349 temperature would be reaction (3), thereby constraining temperature for this sample to 350 the range of 490 to $655^{\circ} \mathrm{C}$.

351 One sample from the Kellys Mountain Gneiss (NS-026) was analyzed for 352 comparison to the contact metamorphic rocks (see Fig. 2 for location). It consists of 353 quartz-K-feldspar-cordierite-biotite-plagioclase, with cordierite sparsely developed in 354 the paleosome, but abundant in the leucosome indicating partial melting. Assuming $f_{\mathrm{H}_{2} \mathrm{O}}=$ 355 1, it therefore plots on the univariant reaction line for (Fig. 6)

$$
\mathrm{Kfs}+\mathrm{Mg}-\mathrm{Crd}+\mathrm{Qtz}+\mathrm{H}_{2} \mathrm{O}=\mathrm{L}
$$

357 but the absence of sillimanite limits it to pressure lower than about $27 \mathrm{MPa}$ by the 358 reaction 1 (Fig. 6). This suggests that the temperature of equilibration of the Kellys 
359 Mountain Gneiss was approximately $725^{\circ} \mathrm{C}$, consistent with the results of Jamieson 360 (1984).

362 Geothermobarometry

363 Methodology

364 Geothermobarometric analysis was done using winTWQ (version 2.3), a software 365 package for performing internally consistent thermobarometric calculations (TWQ;

366 Berman 2007). This method determines the positions of all possible equilibria implied by 367 a given mineral assemblage in terms of $\mathrm{P}-\mathrm{T}-\mathrm{X}_{\mathrm{H}_{2} \mathrm{O}}$ space. Using mineral analyses (Table 368 2), it determines the equilibration conditions recorded by that mineral assemblage, 369 assuming that all components within the rock were in equilibrium with each other during 370 metamorphism and that the conditions for closure of reactions were the same. Multiple 371 reactions can be determined using the program's internally consistent set of

372 thermodynamic parameters, and where these coincide the best estimate of pressure and

373 temperature conditions available can be ascertained.

374 The use of geobarometry and geothermometry is dependent on a thorough 375 understanding of mineral and textural conditions as seen in thin section. Necessary 376 limitations that must be considered when using these tools are (i) the extent of 377 equilibrium at the metamorphic peak, (ii) the effect of retrograde re-equilibrium, (iii) 378 analytical uncertainties, and (iv) the simplifications introduced into thermodynamic 379 formulations of non-ideal solutions (Berman 2007).

380 With regard to (i) and (ii) above, equilibration and retrogression are best 381 evaluated using a combination of textural analysis and careful scrutiny of the mineral 
382 compositions. Rocks that have not equilibrated and/or undergone retrogression show 383 recognizable disequilibrium textures, such as partial or complete replacement, as well as 384 mineral zoning and inter-grain mineral heterogeneity. Such rocks/minerals were avoided 385 in making TWQ calculations. Error in the analysis may arise from retrograde 386 metamorphic re-equilibration, especially in cordierite, garnet, biotite, and muscovite, 387 therefore this possibility must be considered in some samples. Complete replacement by 388 lower grade minerals can be easily identified, but in some minerals homogenization may 389 have occurred or low-grade overgrowths may have formed on the rims. Cordierite, biotite 390 and muscovite are homogeneous within any one sample, and garnet shows less than 5\% 391 variation in composition in one sample and is homogeneous in another (Fig. 5).

392 Individual grains of plagioclase have different compositions, but it was not used in the 393 pressure and temperature determinations using TWQ. Analytical uncertainty (iii above) 394 and overall microprobe data quality were evaluated by making multiple analyses of 395 grains within any given sample and selecting representative analyses. Lastly, the 396 thermodynamic properties used, both standard state values and solution models, are the 397 most up-to-date values available for TWQ (Berman 2007). Non-ideal activity models 398 were used for biotite, garnet, muscovite, and cordierite (Berman 2007). K-feldspar was 399 assumed to be ideal. A non-ideal activity for K-feldspar (Fuhrman and Lindsley 1988) 400 was tested but yielded identical results to ideality presumably because the K-feldspar 401 present is nearly pure $\left(\mathrm{Or}_{94}\right)$. The $a_{\mathrm{H} 2 \mathrm{O}}$ was assumed to be 1.0 in all geothermobarometric 402 calculations. The rocks contain no carbonate (to produce $\mathrm{CO}_{2}$ ) or carbon (to produce $\left.403 \mathrm{CH}_{4}\right)$ and the only phases seen are hydrous. Furthermore, where multiple reactions can be 404 calculated, the best agreement of invariant conditions occurs if $a_{\mathrm{H} 2 \mathrm{O}}$ is set to 1.0. Hydrous 
405 reactions (and their invariant points) all have $\mathrm{H}_{2} \mathrm{O}$ on the high-T/low-P side of the

406 reactions. Reducing the activity of $\mathrm{H}_{2} \mathrm{O}$ expands the $\mathrm{H}_{2} \mathrm{O}$-bearing fields and pushes the

407 equilibria to slightly lower temperatures, thereby causing the hydrous invariant point to

408 differ from other invariant point derivations.

409 Most of the calculated equilibria yield results that confirm previous work and are

410 broadly compatible with field observations. However, equilibria involving muscovite are

411 particularly sensitive to the muscovite composition and the determined pressure

412 conditions of metamorphism in the Glen Tosh formation have higher error bars. Though

413 sample NS-032 yielded a pressure of $250 \mathrm{MPa}$ (Fig. 7A), which is expected in this area of

414 low-pressure metamorphism and compatible with the mineral assemblage, sample NS-

415030 from less than $300 \mathrm{~m}$ away yielded a significantly higher pressure of $460 \mathrm{MPa}$ (Fig.

416 7B). In the case of NS-030, $\mathrm{P}-\mathrm{T}$ conditions are determined by multiple overlapping

417 invariant points, which suggests that the rock has reached equilibrium and that the

418 activity models for all minerals are appropriate. For NS-032, $300 \mathrm{~m}$ farther from the

419 pluton, TWQ calculations produce a plot with a wide web of equilibria and multiple non-

420 overlapping invariant points, which suggests that the minerals did not attain equilibrium.

421 Only the equilibria involving biotite, cordierite, muscovite, quartz and andalusite yield P-

422 T conditions that are reasonable (Fig. 7A). The Fe-Mg exchange between biotite and

423 cordierite is kinetically the most favourable and is likely to be correct. The only other

424 equilibria that cross this reaction at reasonable $\mathrm{P}-\mathrm{T}$ conditions are the two end-members

425 of the reaction

426

$$
\mathrm{Qtz}+2 \mathrm{Bt}+8 \mathrm{And}=3 \mathrm{Crd}+2 \mathrm{Ms}
$$


427 These reactions do not involve $\mathrm{H}_{2} \mathrm{O}$ and thus are not affected by its activity. The invariant

428 point defined by these reactions is shown on Fig. 7A. The discrepancy in recorded

429 pressures between NS-030 (460 MPa) and NS-032 (250 MPa) suggests that either

430 muscovite is not in equilibrium with biotite and cordierite in NS-032 (and the recorded

431 pressure is spurious) or that the higher pressures recorded by multiple invariant points in

432 NS-030 are real and the result of an increase in pressure associated with the intrusion

433 (forceful intrusion).

434 Only temperature could be determined for 3 samples, as shown for samples DM-

43514 (Fig. 7C), RR-202 (Fig. 7D), and NS-026 (Fig. 8).

437 Results - Regional Metamorphism, Glen Tosh Formation

438 The bulk compositions of many of the rocks in the Glen Tosh formation do not

439 generally lend themselves to the development of abundant metamorphic indicator

440 minerals. However, detailed sampling permitted the location of sufficiently low-variance

441 mineral assemblages to provide geothermobarometric analysis. Two samples of the Glen

442 Tosh formation from outside the contact aureole with the dioritic rocks, DM-14 and RR-

443202 (Fig. 2), provide only maximum temperatures (Fig. 7C \& 7D). These rocks likely

444 document the conditions of regional metamorphism as they are remote from the contact,

445 lack cordierite, and have maintained a foliation. Garnet is present in both these samples,

446 so the garnet-biotite ion-exchange reaction (Ferry and Spear 1978) was used to determine

447 the maximum temperature conditions of regional metamorphism. Sample DM-14,

448 approximately $2 \mathrm{~km}$ from the exposed contact, contains quartz-plagioclase-K-feldspar-

449 biotite-garnet. The resulting Fe-Mg exchange reaction between biotite and garnet (Fig. 
450 7C) yields a temperature of $595^{\circ} \mathrm{C}$, assuming a pressure of $300 \mathrm{MPa}$. Sample RR-202

451 contains quartz-plagioclase-muscovite-biotite-garnet-ilmenite, and also produced a

452 reaction line from the Fe-Mg exchange between biotite and garnet (Fig. 6D), with a

453 similar maximum temperature of $585^{\circ} \mathrm{C}$, assuming a pressure of $300 \mathrm{MPa}$. These

454 temperatures are consistent with results obtained for the Kellys Mountain Gneiss by

455 Jamieson (1984) who established temperatures that range from 580 to $700^{\circ} \mathrm{C}$ and

456 pressures that range from 100 to $350 \mathrm{MPa}$.

457

458 Contact Metamorphism, Eastern Glen Tosh formation.

459 Two hornfelsed samples from within $300 \mathrm{~m}$ of contact with the dioritic rocks, NS-

460030 and NS-032 (Fig. 2), were analyzed. Sample NS-030, $<50 \mathrm{~m}$ from the contact,

461 contains the assemblage quartz-plagioclase-K-feldspar-biotite-muscovite-cordierite-

462 sillimanite-spinel, which defines 10 different mineral reactions that all meet at the same

463 invariant point. The reactions are overdetermined (two sets of linearly dependent

464 reactions) and the fact that all the reactions meet at a single invariant point within the

465 stability field of sillimanite provides a robust determination of maximum pressure and

466 temperature conditions of contact metamorphism of $460 \mathrm{MPa}$ at $745^{\circ} \mathrm{C}$ (Fig. $7 \mathrm{~B}$ ).

467 Sample NS-032 consists of a similar mineral assemblage, but contains andalusite

468 instead of sillimanite, which could indicate either a lower temperature or pressure, or

469 both. The assemblage defines three reactions, the positions of which were established

470 from TWQ, yielding a pressure of $250 \mathrm{MPa}$ and a temperature of only $365^{\circ} \mathrm{C}$ (Fig. 7A).

471

472 Regional Metamorphism, Kellys Mountain Gneiss 
For comparison, a maximum regional metamorphic temperature was established

474 from sample NS-026, from the Kellys Mountain Gneiss. The mineral assemblage of

475 quartz-plagioclase-K-feldspar-muscovite-biotite-cordierite-ilmenite allows the use of a

476 cordierite-biotite exchange reaction, yielding a temperature of $715^{\circ} \mathrm{C}$ (Fig. 8), assuming a

477 pressure of approximately $300 \mathrm{MPa}$. This temperature is slightly higher than the range

478 established by Jamieson (1984) of $580-700^{\circ} \mathrm{C}$, but is within the probable error of $\pm 25^{\circ}$.

479

480 U/Pb Monazite Dating

481 Methodology

482 Monazite was dated in polished thin sections using a Resonetics RESOlution ${ }^{\mathrm{TM}}$

483 Series M-50-LR 193nm excimer laser ablation system coupled with an Agilent 7700x

484 quadrupole ICP-MS equipped with dual external rotary pumps. A crater size of $13 \mu \mathrm{m}, 3$

$485 \mathrm{~Hz}$ repetition rate, $\sim 2 \mathrm{~J} / \mathrm{cm}^{2}$ fluence, 30 second ablation time following 30 seconds of

486 background collection was used. Ablation sequences comprised at least 15 well-

487 characterized U-Pb age standards (GSC-8153 monazite) that were distributed so as to

488 bracket blocks of 3 to 5 unknowns. Additional standards (e.g., 44069 monazite) were also

489 included and used to check the accuracy of the method. Ablated aerosols were carried out

490 of the Laurin Technic two-volume sample cell using pure He at a flow rate of 750

$491 \mathrm{~mL} / \mathrm{min}$. This was mixed with $650 \mathrm{~mL} / \mathrm{min}$ of Ar carrier gas and $2.8 \mathrm{~mL} / \mathrm{min} \mathrm{N}_{2}$ which is

492 used to enhance ionization efficiency in the ICP-MS plasma. Before entering the ICP-MS

493 torch, the combined gas stream passes through a smoothing device (Laurin Technic

494 'squid'). The Agilent 7700x ICP-MS was operated at an RF power of $1450 \mathrm{~W}$ with ion

495 lenses tuned to obtain $<0.3 \% \mathrm{ThO}^{+} / \mathrm{Th}$ and $\mathrm{U}^{+} / \mathrm{Th}^{+} \sim 1.05$ as measured on NIST610 
496 reference glasses. One sweep of the ICP-MS quadrupole comprised a rapid $(0.01 \mathrm{sec})$

497 measurement of a guide mass (e.g., ${ }^{31} \mathrm{P}$ for monazite) followed by ${ }^{204} \mathrm{~Pb}(0.08 \mathrm{sec}),{ }^{206} \mathrm{~Pb}$

498 (0.03 sec), ${ }^{207} \mathrm{~Pb}(0.07 \mathrm{sec}),{ }^{208} \mathrm{~Pb}(0.01 \mathrm{sec}),{ }^{232} \mathrm{Th}(0.01 \mathrm{sec})$, and ${ }^{238} \mathrm{U}(0.02 \mathrm{sec})$. This

499 gave a total measurement time of $\sim 0.25$ seconds per sweep or $\sim 120$ measurements per 30

500 second ablation. The ICP-MS datafile (data as counts/sec) and laser sequence log file

501 were combined offline in Iolite v. 2.5 and ages calculated using the VizualAge U-Pb

502 geochronology data reduction scheme described by Petrus et al., (2011). Additional

503 details concerning the technique used are provided in McFarlane (2015).

505 Results

506 Monazite was analyzed in sample NS-030, from within $50 \mathrm{~m}$ of the contact with

507 the Kellys Mountain dioritic rocks. This rock exhibits a hornfelsic texture in hand

508 specimen, and is completely recrystallized in thin section, with a well-developed fine-

509 grained triple point fabric among quartz and feldspars and no relict foliation. It is

510 compositionally layered, with a dominant quartz-plagioclase-K-feldspar-biotite-

511 muscovite-sillimanite assemblage and subordinate plagioclase-cordierite-ilmenite-

512 spinel domains. Monazite occurs in both domains, but is larger, up to $100 \mu \mathrm{m}$ across, and

513 idioblastic in the latter domain, where it was analyzed. No zoning in the monazite was

514 detected optically.

515 The results of in-situ $\mathrm{U}-\mathrm{Pb}$ monazite dating are given in Table 3. Common $\mathrm{Pb}$ is

516 less than $2 \%$ of total $\mathrm{Pb}$ analyses in most cases. Four analyses identified in Table 3

517 comprise a cluster of concordant overlapping ellipses and yield the youngest near-

518 concordant data (Fig. 9). The blue ellipse, which yields an age of 480.9 $\pm 3.7 \mathrm{Ma}$, 
519 represents the weighted mean error ellipse for the population and is taken as the best

520 estimate of the timing of monazite (re)crystallization.

521 The age of regional metamorphism in Kellys Mountain has previously been

522 determined as $515 \pm 1$ Ma (Keppie et al. 1998) in the Kellys Mountain Gneiss. The co-

523 magmatic granitic and dioritic rocks then intruded at $498 \pm 2 \mathrm{Ma}$ (Barr et al. 1990),

524 followed by rapid exhumation of plutonic rocks and gneiss through the closure

525 temperatures of titanite $(\mathrm{U} / \mathrm{Pb})$ and hornblende $\left({ }^{40} \mathrm{Ar} /{ }^{39} \mathrm{Ar}\right)$ at $496 \pm 5 \mathrm{Ma}$ and $495.8 \pm 2.8$

526 Ma respectively (Keppie and Dallmeyer 1989, Keppie et al. 1998). The monazite

527 crystallization age of $481 \pm 4$ Ma (Fig. 9) determined for sample NS-030 in this study

528 using in-situ U-Pb methods indicates that plutonism must have continued for another 15

529 m.y., which is compatible with the observation that several plutons have been mapped in

530 this area. This younger age is presumably restricted to the contact aureole in the Glen

531 Tosh formation.

532

533 Discussion

534 Conditions of regional and contact metamorphism

535 Regional metamorphism in the study area ranges from biotite grade phyllite

536 through andalusite and cordierite-bearing phyllite and metamorphosed quartz wacke, to

537 sillimanite-cordierite gneiss in the Kellys Mountain block. Previously, it was thought that

538 these comprised two separate regional metamorphic events (Barr et al. 1995), but the

539 results of this study and a parallel investigation by Barr et al. (2013) now call this

540 interpretation into question. Superimposed on the low-grade regional metamorphism of

541 the Glen Tosh formation is a narrow metamorphic contact aureole located west of the 
542 Kellys Mountain diorite intrusion. The rocks of the contact metamorphic zone contain

543 sillimanite and cordierite, indicating higher temperatures of metamorphism compared to

544 the regional metamorphism of the Glen Tosh formation.

545 The Glen Tosh formation is a regional low-grade metamorphic unit typical of the

546 Bras d'Or terrane that underwent low-grade low-pressure, high-heat flow metamorphism

547 prior to undergoing contact metamorphism at 480.9 $\pm 3.7 \mathrm{Ma}$. Multi-equilibrium

548 calculations derived from TWQ have yielded metamorphic pressures in the range of 250

549 to $460 \mathrm{MPa}$ and temperatures that range from 365 to $760^{\circ} \mathrm{C}$, which are compatible with

550 the observed mineral assemblages. The progressive appearance of andalusite, sillimanite

551 and cordierite in samples with hornfelsic texture closer to the contact supports the

552 conclusion that these rocks underwent a superimposed contact metamorphism. The

553 visible effects of neocrystallization and hornfels development extend up to $300 \mathrm{~m}$ from

554 the plutonic contacts, suggesting a steep contact.

555 The estimated pressure of $250 \mathrm{MPa}$ indicates that the plutons of Kellys Mountain

556 intruded at depths of $9-10 \mathrm{~km}$ below the surface. Although the two plutonic units of

557 Kellys Mountain most likely intruded at similar times, based on field observations,

558 temperatures up to $590^{\circ} \mathrm{C}$ in the hornfelsed aureole indicate that the hotter Kellys

559 Mountain diorite and not the Kellys Mountain Granite were likely the principal agent of

560 contact metamorphism.

561 The much higher pressure of $460 \mathrm{MPa}$ and temperature of $745^{\circ} \mathrm{C}$ from a rock

562 immediately adjacent to the contact with the diorite is anomalous, being higher than any

563 other P-T conditions determined in Kellys Mountain. These conditions result from

564 calculations involving two separate invariant systems (Fig. 7B), and hence we conclude 
565 that they are robust, and indicate that the rocks closest to the contact have been exhumed

566 from greater depths, possibly implying forcible intrusion of the diorite.

568 Kellys Mountain Gneiss Comparison

569 Regionally metamorphosed rocks in the Kellys Mountain Gneiss have a similar

570 mineral assemblage to the Glen Tosh formation. At the highest grade, both andalusite and

571 sillimanite have been reported in a sample of cordierite migmatite (Jamieson 1984).

572 Calculated temperatures range from 580 to $715^{\circ} \mathrm{C}$ at pressures ranging from 100 to 350

$573 \mathrm{MPa}$, which overlap the range of pressure and temperature conditions seen in the contact

574 metamorphism in the Glen Tosh formation, but exceed the temperatures recorded by the

575 regional metamorphism of the Glen Tosh formation.

576 Barr et al. (2013) compared the whole-rock and $\mathrm{Nd}$ isotopic compositions of the

577 Glen Tosh formation and the Kellys Mountain Gneiss and established that they are

578 geochemically and isotopically similar. Furthermore, Barr et al. (2013) provided rare-

579 earth element distribution patterns that are identical for the two units, and concluded that

580 the Glen Tosh formation and the Kellys Mountain Gneiss are of the same protolith and

581 may have been affected by the same regional metamorphic history. If the Kellys

582 Mountain Gneiss is correlated with the Glen Tosh formation, as suggested by Barr et al.

583 (2013), regional metamorphic grade must increase from the southwest to northeast along

584 Kellys Mountain.

585 Dating of the Kellys Mountain Gneiss has previously established ages of $515 \pm 1$

$586 \mathrm{Ma}(\mathrm{U}-\mathrm{Pb}$ in monazite, Keppie et al. 1998) and $496 \pm 5 \mathrm{Ma}(\mathrm{U}-\mathrm{Pb}$ in titanite, Dunning et

587 al. 1990) and several ${ }^{40} \mathrm{Ar} /{ }^{39} \mathrm{Ar}$ ages ranging from $498 \pm 3.5$ to $493 \pm 1.5 \mathrm{Ma}$ (Reynolds et 
588 al. 1989; Keppie and Dallmeyer 1989) (Fig. 2). The older 515 Ma monazite age was

589 interpreted by Keppie et al. (1998) to be the result of heating of earlier metamorphosed

590 rocks, not themselves dated on Kellys Mountain, by the intrusion of the Kellys Mountain

591 Granite. The titanite age aligns with various ${ }^{40} \mathrm{Ar} /{ }^{39} \mathrm{Ar}$ cooling ages. This study provides

592 the youngest age, $480 \pm 3.7 \mathrm{Ma}$, from the rocks of the contact metamorphic aureole,

593 which suggests that the pluton that formed the contact aureole is younger still.

594

595 Tectonic Implications

596 This investigation of the petrology, geothermobarometry and isotopic dating of

597 the Kellys Mountain Gneiss and Glen Tosh formation shows that they could have initially

598 undergone a regional, low-pressure, high-heat flow regional metamorphic event at the

599 same time.

600 Low-pressure regional metamorphism, like that preserved in the Kellys Mountain

601 Gneiss and the Glen Tosh formation, can develop in several tectonic environments: (i)

602 crustal thickening (Looseveld and Etheridge 1990, Sandiford and Powell 1991), (ii) high-

603 heat flow metamorphism (De Yoreo et al. 1991) (iii) rifting and associate magma

604 upwelling (De Yoreo et al. 1991), and (iv) low-angle extension core complex with mantle

605 upwelling (Wernicke 1985).

606 A continental collision zone and associated crustal thickening can produce heat

607 derived from the greater thickness of continental crust with its higher radioactive element

608 content, and is commonly associated with S-type plutonism (Looseveld and Etheridge

609 1990, Sandiford and Powell 1991), such as the Kellys Mountain Granite. Above a

610 subduction zone calc-alkaline plutons of the same age as the metamorphism would be 
611 expected to be present (De Yoreo et al. 1991), and this is the case for the calc-alkaline

612 plutons in Kellys Mountain (Fig. 2; Keppie and Dallmeyer 1989, Barr et al. 1990) and the

613 extensive suite of supra-subduction zone plutons north of Kellys Mountain in the Cape

614 Breton Highlands.

615 The other proposed mechanisms for high-heat flow metamorphism are less likely

616 in Kellys Mountain. Rift-related metamorphism from crustal thinning and magmatic

617 upwelling (De Yoreo et al. 1991) or Wernicke-type metamorphic core complex

618 development (Wernicke 1985) would likely be accompanied by extension, such as graben

619 development and associated faulting, not recognised in the Bras d'Or terrane.

620 Hence we conclude that a collision zone and associated crustal thickening

621 occurring above an island arc or continental margin subduction zone is the most plausible

622 setting for the metamorphic events that occurred at Kellys Mountain. Plutons of similar

623 ages as the metamorphism are present (Fig. 2) and the protolith of the metapsammite of

624 the Glen Tosh formation (quartz-wacke), a lithology likely incorporated into a subduction

625 zone complex prior to undergoing metamorphism, is representative of the accretionary

626 prism of an subduction zone. Low-pressure regional metamorphism is a result of crustal

627 thickening and is also seen in extensions of the Bras d'Or terrane in the Grey River

628 Gneiss, Newfoundland (Raeside and Barr 1990), and the Brookville terrane of southern

629 New Brunswick (White and Barr 1996).

630 Following the period of high-heat flow metamorphism, emplacement of the

631 Kellys Mountain Granite and the Kellys Mountain dioritic rocks caused contact

632 metamorphism, overprinting the regional metamorphism. Calculated conditions of

633 metamorphism of $250 \mathrm{MPa}$ and temperatures up to $590^{\circ} \mathrm{C}$ at $480.9 \pm 3.7 \mathrm{Ma}$ imply that 
634 the plutons intruded at about $9 \mathrm{~km}$ depth. Higher calculated pressure conditions

635 immediately adjacent to the pluton contact imply forcible intrusion and uplift of rocks

636 from deeper levels in the crust.

637

638 Comparison of metamorphic units within the Bras d'Or terrane

639 The Bras d'Or terrane contains numerous other metamorphic units including the 640 Lime Hill Gneissic Complex, Skye Mountain Metamorphic Suite and the Frenchvale

641 Road Metamorphic Suite, all of which have been included with the Kellys Mountain

642 Gneiss as the Bras d'Or Metamorphic Suite (Raeside and Barr 1990, White et al. 2016)

643 (Fig. 1). Metamorphic conditions in these units range from a pressure less than $400 \mathrm{MPa}$ 644 at over $650^{\circ} \mathrm{C}$ (Lime Hill Gneiss: Raeside 1990) to $280 \mathrm{MPa}$ at $580^{\circ} \mathrm{C}$ (Frenchvale Road 645 Metamorphic Suite: Walker 1988) and to 200 to $350 \mathrm{MPa}$ at 525 to $650^{\circ} \mathrm{C}$

646 (Whycocomagh Mountain Gneiss: Armitage 1989, Swanton et al. 2010).

647 Other metamorphic units of the Bras d'Or terrane include the generally low-grade 648 components of the George River Metamorphic Suite, which typically display greenschist649 facies metamorphic assemblages. Only where they extend north into the Cape Breton 650 Highlands do they display amphibolite-facies metamorphism.

651 Metamorphism in the Glen Tosh formation, as a component of the George River 652 Metamorphic Suite, and the Kellys Mountain Gneiss, as a component of the Bras d'Or 653 Metamorphic Suite, is characteristic of the broader area of the Bras d'Or terrane. Both 654 units underwent relatively low-pressure regional metamorphic events, however, in Kellys 655 Mountain the intrusion of supra-subduction zone plutonic rocks resulted in continued 
656 high-heat flow metamorphism in the higher grade units and the last pulse of

657 metamorphism was limited to contact metamorphic effects in lower grade rocks.

659 Acknowledgments

All findings were part of a BSc (Honours) thesis at Acadia University by the first

author. S.M. Barr is acknowledged for providing rock samples, thin sections, and some

662 figures that have been further modified. Retired technician, Don Osburn, is thanked for

663 his assistance in petrographic preparations. C.E. White, one anonymous reviewer, and a

664 journal editor are thanked for helpful criticism of earlier versions of the manuscript.

665 Funding for this project was provided by Acadia University.

666

667 References

668 Armitage, A. 1989. Geology and petrology of the crystalline rocks of the Whycocomagh area, Cape Breton Island, Nova Scotia. Honours Thesis, Cape Breton.

670 Barr, S.M., and Raeside, R.P. 1989. Tectono-stratigraphic terranes in Cape Breton Island,

671 Nova Scotia: Implications for the configuration of the northern Appalachian orogen. Geological Society of America, 17(9): 822-825.

673 Barr, S.M., Dunning, G.R., Raeside, R.P., and Jamieson R.A. 1990. Contrasting U-Pb ages from plutons in the Bras d'Or and Mira terranes of Cape Breton Island, Nova Scotia. Canadian Journal of Earth Sciences, 27(9): 1200-1208.

676 Barr, S.M., Jamieson, R.A., and Raeside, R.P. 1992. Geology of northern Cape Breton Island, Nova Scotia. Geological Survey of Canada, Coloured Map 1752A, scale

678 $1: 100,000$. 
679 Barr, S.M., O'Reilly, G.A., and O'Beirne, A.M. 1982. Geology and geochemistry of

680

681

682

683 selected granitoid plutons of Cape Breton Island. Province of Nova Scotia, Department of Mines and Energy, Paper 82-1, 177 p.

Barr, S.M., Pin, C., McMullin, D.W.A, and White, C.E. 2013. Whole-rock chemical and Sm-Nd isotopic composition of a Lake Proterozoic metasedimentary sequence in Ganderia: Kellys Mountain, Bras d'Or Terrane, Nova Scotia, Canada. Atlantic Geology, 49: 57-69.

Barr, S.M., Raeside, R.P. and White, C.E. 1998. Geological correlations between Cape Breton Island and Newfoundland, northern Appalachian orogen. Canadian Journal of Earth Sciences, 35:1252-1270.

Barr, S.M., Raeside, R.P., Miller, B.W., and White, C.E. 1995. Terrane evolution and accretion in Cape Breton Island, Nova Scotia, In Current Perspectives in Appalachian-Caledonian Orogen. Edited by Hibbard, J.P., van Staal, C.R., and Cawood, P.A. Geological Association of Canada, Special Paper 41: 391-407.

Barr, S.M., White, C.E., Davis, D.W., McClelland, W.C., and van Staal, C.R. 2014. Infrastructure and provenance of Ganderia: evidence from detrital zircon ages in the Brookville terrane, southern New Brunswick, Canada. Precambrian Research 246: $358-370$.

Berman, R.G. 2007. winTWQ (version 2.3): a software package for performing internally-consistent thermobarometric calculations. Geological Survey of Canada, Open File 5462 (revised).

Bhattarcharya, A. 1986. Some geobarometers involving cordierite in the $\mathrm{FeO}-\mathrm{Al}_{2} \mathrm{O}_{3}-$ $\mathrm{SiO}_{2}\left( \pm \mathrm{H}_{2} \mathrm{O}\right)$ system: refinements, thermodynamic calibration, and applicability in 
702

703

704

705

706

707

708

709

710

711

712

713

714

715

716

717

718

719

720

721

722

723

724

granulite facies rocks. Contributions to Mineralogy and Petrology, 94(3): 387394.

Campbell, J. 1990. The geology of northeastern Creignish Hills, Cape Breton Island, Nova Scotia. Masters Thesis, Acadia University.

De Yoreo, J.J., Lux, D.R., Guidotti, C.V. 1991. Thermal modeling in low-pressure/hightemperature metamorphic belts. Tectonophysics, 188(3-4): 209-238.

Dunning, G.R., Barr, S.M., Raeside, R.P., and Jamieson, R.A. 1990. U-Pb zircon, titanite, and monazite ages in the Bras d'Or and Aspy terranes of Cape Breton Island, Nova Scotia: Implications for magmatic and metamorphic history. Geological Society of America Bulletin, 102: 322-330.

Ferry, J.M., and Spear, F.S. 1978. Experimental calibration of the partitioning of Fe and Mg between biotite and garnet. Contributions to Mineralogy and Petrology, 66(2): 113-117.

Fettes, D., and Desmons, J. 2007. Metamorphic Rocks: A Classification and Glossary of Terms. Recommendations of the International Union of Geological Sciences. Cambridge University Press. Cambridge. 244 p.

Fuhrman, M.K., and Lindsley, D.H. 1988. Ternary-feldspar modeling and thermometry American Mineralogist, 73(3-4): 201-215.

Hibbard, J.P., van Staal, C.R., Rankin, D.W., and Williams, H. 2006. Lithotectonic map of the Appalachian Orogen, Canada-United States of America, Geological Survey of Canada, "A" Series Map: 2 sheets, Geological Survey of Canada.

Holdaway, M.J. 1971. Stability of andalusite and the aluminum silicate phase diagram. American Journal of Science, 271(1): 97-131. 
725 Jamieson, R.A. 1984. Low pressure cordierite-bearing migmatites from Kellys Mountain, 726 Nova Scotia. Contributions to Mineralogy and Petrology, 86: 309-320.

727 Keppie, J.D., and Dallmeyer, R.D. 1989. ${ }^{40} \mathrm{Ar} /{ }^{39} \mathrm{Ar}$ mineral ages from Kellys Mountain,

728 Cape Breton Island, Nova Scotia; implications for the tectonothermal evolution of

729 the Avalon composite terrane. Canadian Journal of Earth Sciences, 26(8): 1509-

$730 \quad 1516$.

731 Keppie, J.D., Davis, D.W., and Krogh, T.E. 1998. U-Pb geochronological constraints on

732 Precambrian stratified units in the Avalon Composite Terrane of Nova Scotia,

733 Canada: tectonic implications. Canadian Journal of Earth Sciences, 35(3): 222-

734236.

735 McFarlane, C.R.M. 2015. A geochronological framework for sedimentation and

736 Mesoproterozoic tectono-magmatic activity in lower Belt-Purcell rocks exposed

737 west of Kimberley, British Columbia. Canadian Journal of Earth Sciences, 52(7):

$738 \quad 444-465$.

739 Martignole, J., and Sisi, J.-C. 1981. Cordierite-garnet- $\mathrm{H}_{2} \mathrm{O}$ equilibrium: a geological

740 thermometer, barometer and water fugacity indicator. Contributions to

$741 \quad$ Mineralogy and Petrology, 77(1): 38-46.

742 Pattison, D., and Harte, B. 1985. A petrogenetic grid for pelites in the Ballachulish and

743 other Scottish thermal aureoles. Journal of the Geological Society of London, $744 \quad$ 142(1): 7-28.

745 Raeside, R.P. 1990. Low pressure metamorphism of the Lime Hill Gneiss, Bras d'Or

746 Terrane, Cape Breton Island, Nova Scotia. In Geology of mineral deposits of 

Nova Scotia, Edited by A. Sangster. Geological Survey of Canada, Paper 90-8: 67-76.

Raeside, R.P. and Barr, S.M. 1990. Geology and tectonic development of the Bras d'Or suspect terrane, Cape Breton Island, Nova Scotia. Canadian Journal of Earth Sciences, 27(10): 1371-1381.

Raeside, R.P. and Barr, S.M. 1992. Geology of the northern and eastern Cape Breton Highlands, Nova Scotia. Geological Survey of Canada, Paper 89-14, 39 p. 
Scotia. BSc Honours thesis, Acadia University, Wolfville, NS, Canada (CAN),

771 $137 \mathrm{p}$.

772 Wernicke, B. 1985. Uniform-sense normal simple shear of the continental lithosphere.

773 Canadian Journal of Earth Sciences, 22(1): 108-125.

774 White, C.E. and Barr, S.M. 1996. Geology of the Brookville terrane, southern New

775 Brunswick, Canada. In Avalonian and Related Peri-Gondwanan Terranes of the 776 Circum-North Atlantic. Edited by R.D. Nance and M.D. Thompson. Geological $777 \quad$ Society of America Special Paper 304:133-147.

778 White, C.E., Barr, S.M., Bevier, M.L. and Kamo, S. 1994. A revised interpretation of 779 Cambrian and Ordovician rocks in the Bourinot belt of central Cape Breton 780 Island, Nova Scotia. Atlantic Geology, 30(2): 123-142.

781 White, C.E., Barr, S.M., Davis, D.W., Swanton, D.S., Ketchum, J.W.F., and Reynolds, 782 P.H. 2016. Field relations, age, and tectonic setting of metamorphic and plutonic 783 rocks in the Creignish Hills - North Mountain area, southwestern Cape Breton Island, Nova Scotia, Canada. Atlantic Geology, 52: 35-57. 


\section{Table Captions}

787 Table 1. List of mineral assemblages \pm zircon, monazite and xenotime for relevant

788 samples. $\mathrm{x}=$ present, $1=$ prograde, $2=$ retrograde, $\mathrm{h}=$ hematite, $\mathrm{i}=$ ilmenite, $\mathrm{m}=$

789 magnetite, $\mathrm{c}=$ chloritized, $\mathrm{p}=$ pinitized.

790

791 Table 2. Electron microprobe analyses of co-existing minerals for various samples that

792 were subsequently input into TWQ.

793

794 Table 3. Isotope data acquired to calculate ages of monazite using a laser ablation ICP-

795 MS. The four bolded rows represent data used to calculate the Concordia age, which

796 correspond to the black ellipses in Fig. 9. It should be noted that the symbol * represents

797 analyses where xenotime was possibly measured rather than monazite based on the $\mathrm{Nd}$ 798 and $\mathrm{U}$ contents.

799 


\section{Figure Captions}

801 Fig. 1. Regional geology of the Bras d'Or terrane, Cape Breton Island where the location 802 is given relative to Nova Scotia. Red box indicates location of Kellys Mountain.

803 Modified from Barr et al. (2013). Abbreviations: BBF $=$ Blues Brook Formation, $\mathrm{BF}=$ 804 Benacadie Brook Formation, BRMS = Barachois River Metamorphic Suite, FRMS = 805 Frenchvale Road Metamorphic Suite, GTf = Glen Tosh formation, $\mathrm{KMG}=$ Kellys 806 Mountain Gneiss, LHGC = Lime Hill Gneissic Complex, MFF = McMillan Flowage 807 Formation, $\mathrm{MF}=$ Malagawatch Formation, $\mathrm{SMMS}=$ Skye Mountain Metamorphic Suite 808 Inset: location of Cape Breton Island in the northern Appalachian orogen.

810 Fig. 2. The geology of Kellys Mountain and Big Hill, Cape Breton Island, Nova Scotia, 811 with locations of previous dating work and $\mathrm{U} / \mathrm{Pb}$ monazite dating of this study. Modified 812 from Barr et al. (2013). The Glen Tosh formation (grey) extends from the western end of 813 Kellys Mountain into Big Hill and north into the southern Cape Breton Highlands.

814 Samples found in the area shown on the map have undergone electron microprobe 815 analysis. Modified from Barr et al. (2013).

817 Fig. 3. Photomicrographs of psammitic and pelitic rocks of the Glen Tosh formation. A) 818 Sample NS-034, ca. $1 \mathrm{~km}$ from contact, showing well-developed foliation, and large 819 altered cordierite clusters (Crd). B) Sample NS-030 from adjacent to the contact showing 820 the same lithology as in a), recrystallized as hornfels. Cordierite is visible as altered 821 grains of moderate relief in the lower left. C) Sample NS-030 showing sillimanite (Sil) 822 interlocking between quartz grains. D) Sample NS-032 showing biotite overgrowing 
823 andalusite (And). Scale bars in a-c are $200 \mu \mathrm{m}$, in d $100 \mu \mathrm{m}$.

824

825 Fig. 4. Field photographs of outcrops found at Kellys Mountain. A) Contact between

826 meta-quartz wacke of the Glen Tosh formation and dioritic rocks along the Great Bras

827 d'Or shoreline. B) Photograph taken by S.M. Barr of the Kellys Mountain Granite (pink)

828 cross-cutting the Kellys Mountain dioritic rocks (grey). Outcrop is approximately

8295 metres high.

830

831 Fig. 5. Backscatter electron images. A, cordierite in a recrystallized matrix of plagioclase

832 and ilmenite, sample NS-030. B, garnet in a matrix of foliated biotite, muscovite and

833 quartz and feldspar in sample RR-202.

834

835 Fig. 6. Phase diagram of KFMASH system, $\mathrm{a}_{\mathrm{H}_{2} \mathrm{O}}=1$. Modified from Pattison

836 and Harte (1985), $a_{\mathrm{H}_{2} \mathrm{O}}=1$. Numbered reactions correlate to reactions given in text.

838 Fig. 7. Pressure and temperature conditions of the Glen Tosh formation. A) TWQ results

839 for sample NS-032 providing pressures of $250 \mathrm{MPa}$ and temperatures of $365^{\circ} \mathrm{C}$. B) TWQ

840 results for sample NS-030 providing pressures of $460 \mathrm{MPa}$ and temperatures of $745^{\circ} \mathrm{C}$.

841 C) TWQ results for sample DM-14 providing a maximum temperature of $595^{\circ} \mathrm{C}$. D)

842 TWQ results for sample RR-202 providing a maximum temperature of $585^{\circ} \mathrm{C}$.

843

844 Fig. 8. TWQ results for Kellys Mountain Gneiss sample NS-026 providing a maximum

845 temperature of $715^{\circ} \mathrm{C}$. 
847 Fig. 9. U/Pb monazite dating results of sample NS-030. The blue ellipse is the concordia 848 age of the weighted mean of the data points based on the four black ellipses. 


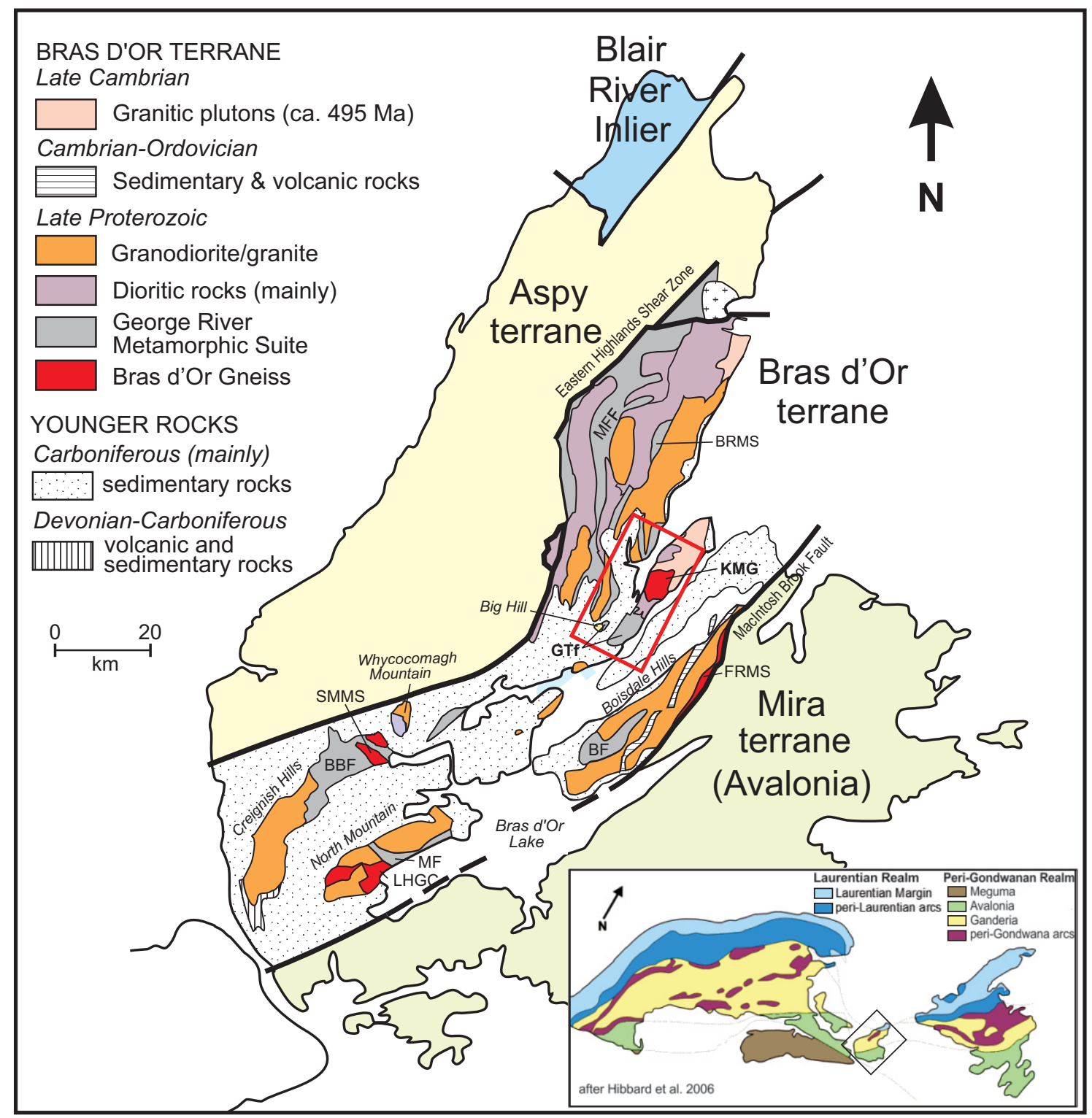




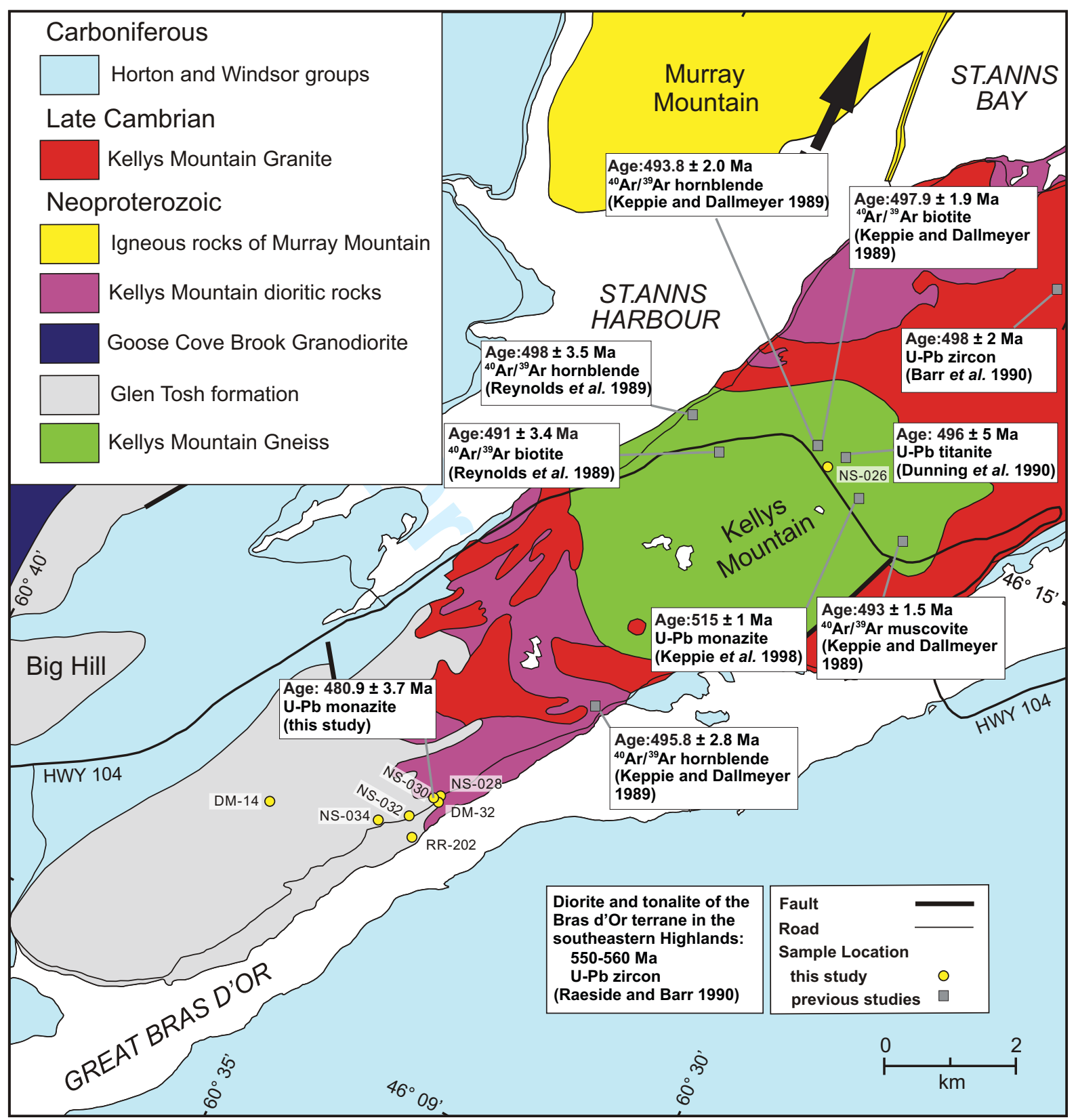




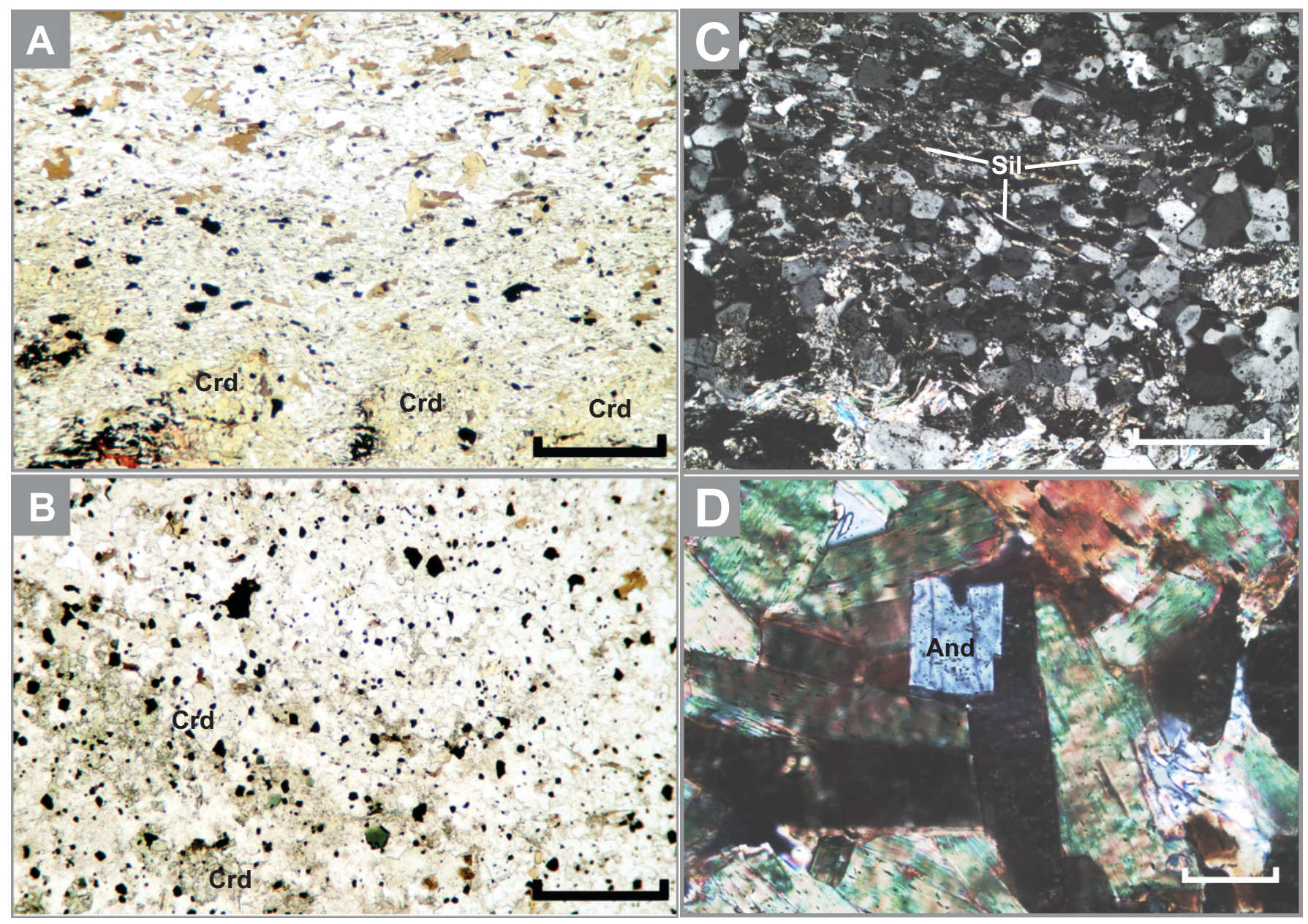




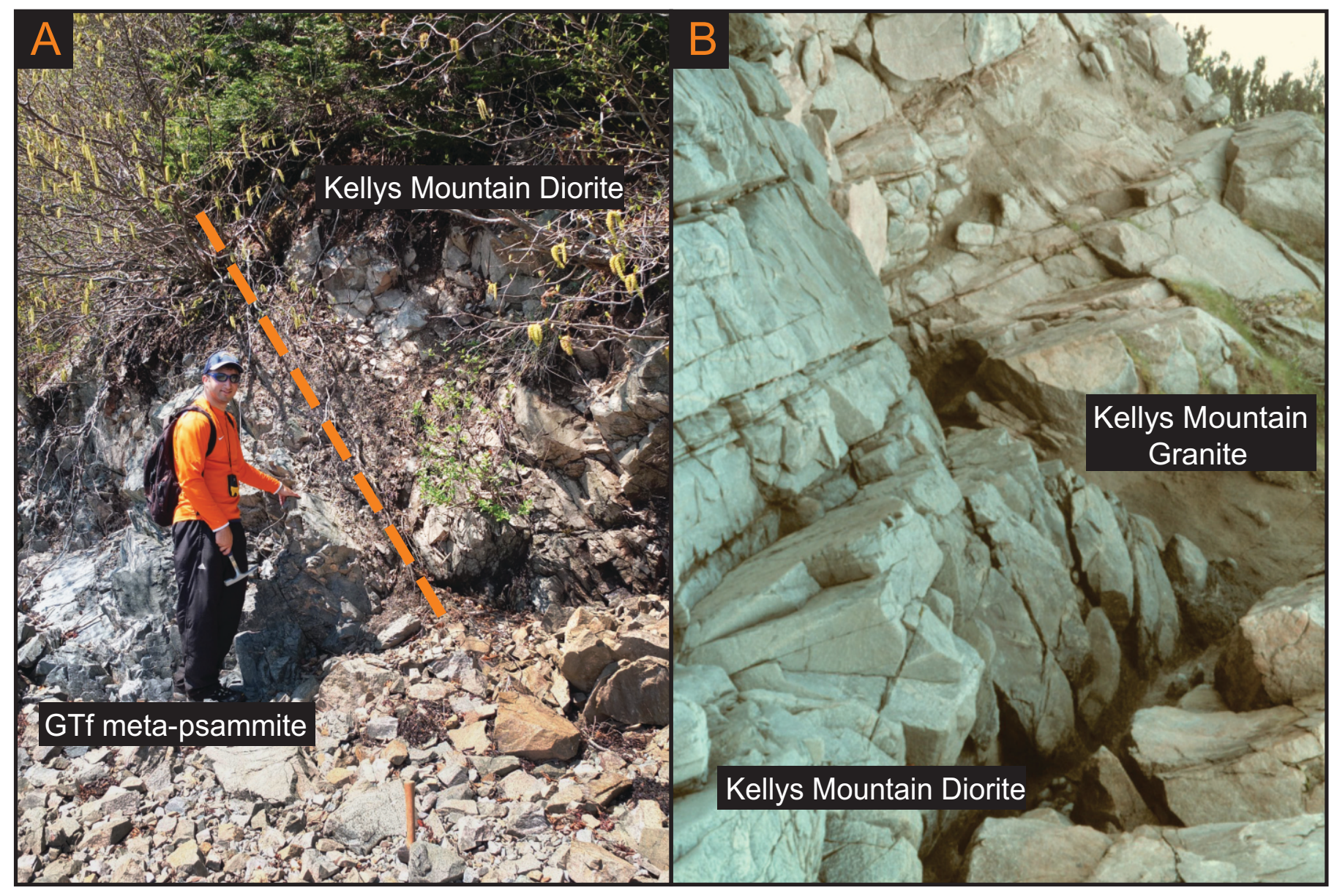




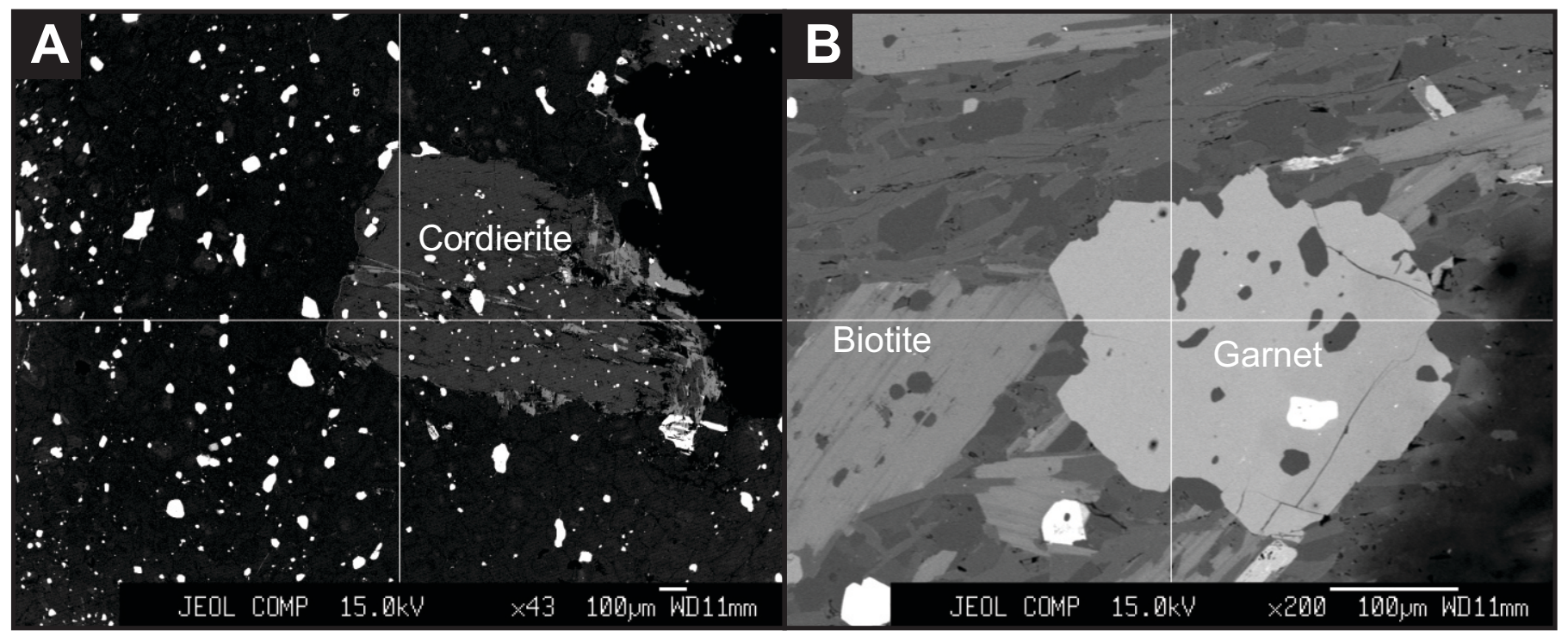




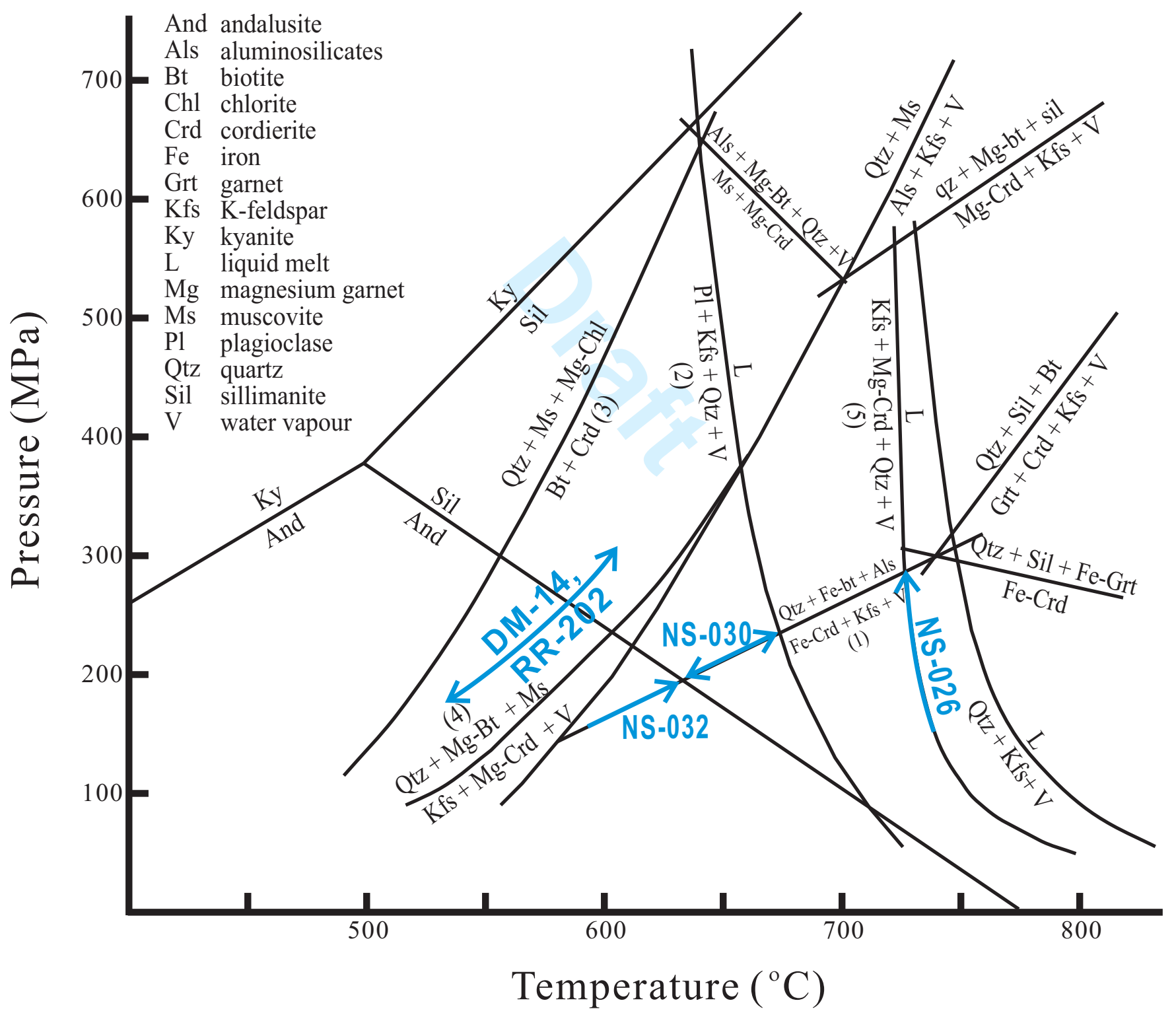



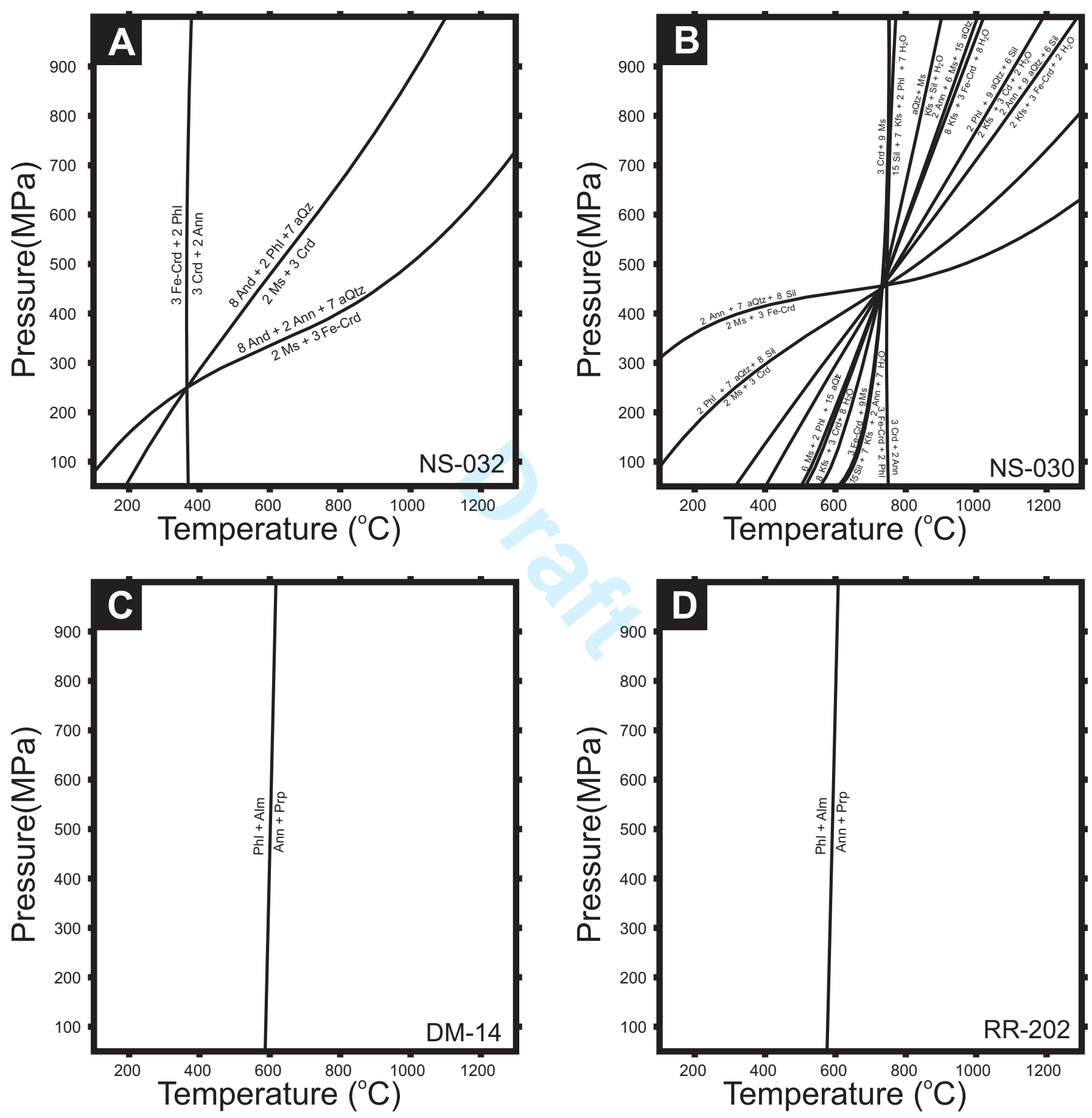


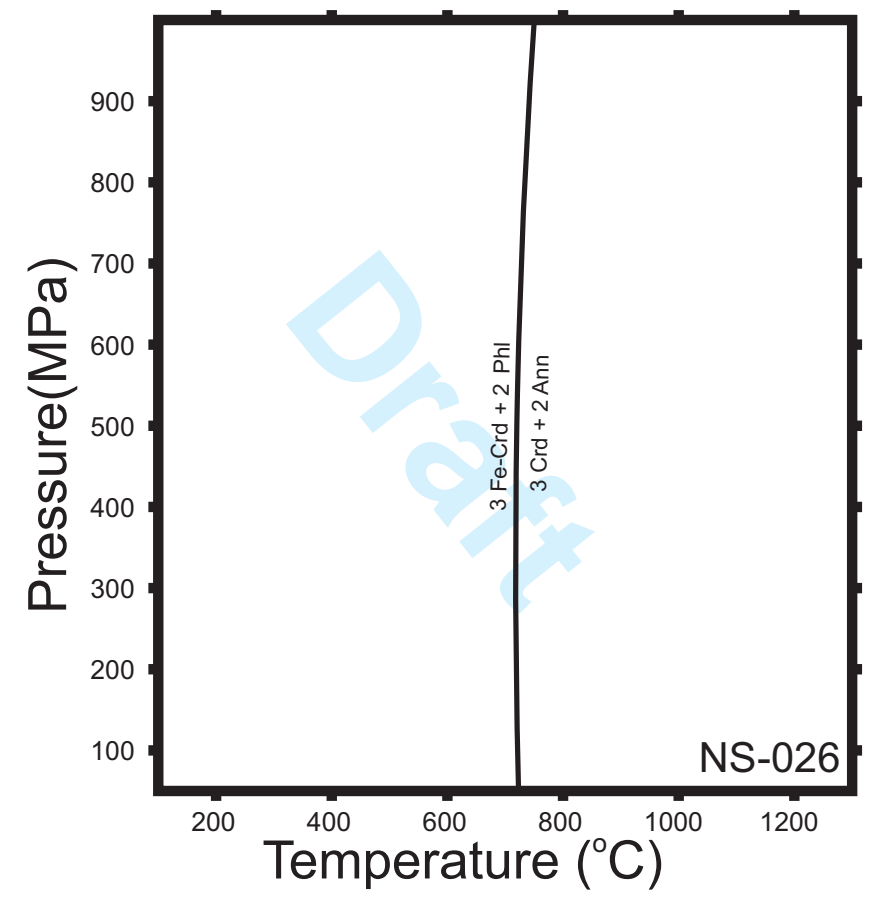

https://mc06.manuscriptcentral.com/cjes-pubs 


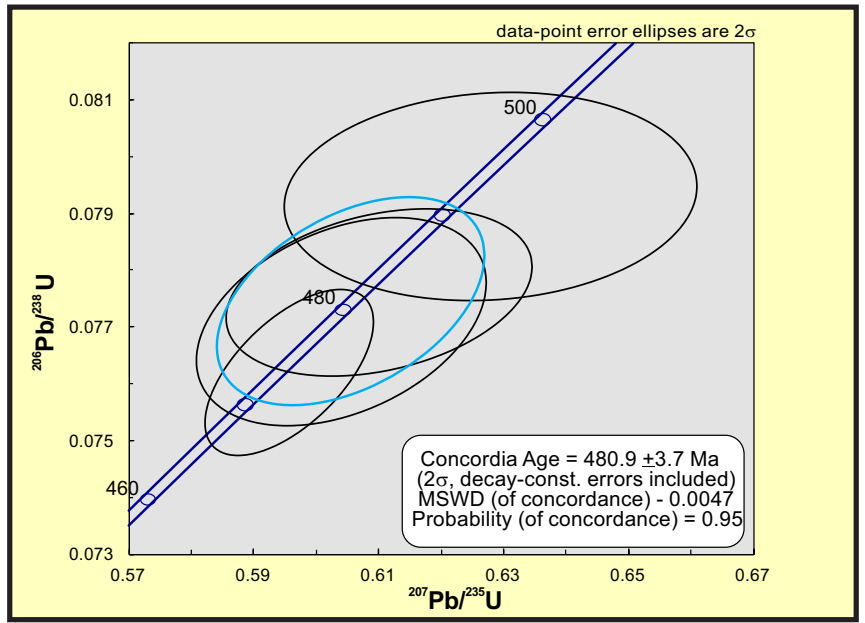

https://mc06.manuscriptcentral.com/cjes-pubs 


\begin{tabular}{|c|c|c|c|c|c|c|c|c|c|c|c|c|c|c|c|c|}
\hline Sample \# & UTM coordinates & Lithology & $\mathbf{Q z}$ & Pl & Kfs & $\mathbf{B t}$ & Ms & Crd & Grt & And & Sil & Opq & Tur & $\mathbf{E p}$ & Ser & Chl \\
\hline NS-026 & 690477,5125013 & Paragneiss & $\mathrm{x}$ & $\mathrm{x}$ & $\mathrm{x}$ & $\mathrm{x}$ & 12 & $\mathrm{x}$ & $\mathrm{x}$ & & & $\mathrm{xi}$ & $\mathrm{x}$ & & 2 & 2 \\
\hline NS-028 & 687546,5117892 & Meta-psammite & $\mathrm{x}$ & $\mathrm{x}$ & $\mathrm{x}$ & $\mathrm{x}$ & 1 & $\mathrm{x}$ & & & & $\mathrm{x}$ i m & $\mathrm{x}$ & & & \\
\hline NS-030 & 687596,5117831 & Meta-psammite & $\mathrm{x}$ & $\mathrm{x}$ & $\mathrm{x}$ & $\mathrm{x}$ & 12 & $\mathrm{x}$ & $\mathrm{c}$ & & $\mathrm{x}$ & $\mathrm{x}$ i m & $\mathrm{x}$ & & & 2 \\
\hline NS-032 & 687598,5117587 & Meta-psammite & $\mathrm{x}$ & $\mathrm{x}$ & $\mathrm{x}$ & $\mathrm{x}$ & 12 & $\mathrm{x}$ & & $\mathrm{x}$ & & $\mathrm{x}$ i m & $\mathrm{x}$ & & & \\
\hline NS-034 & 687342,5117287 & Meta-psammite & $\mathrm{x}$ & $\mathrm{x}$ & & $\mathrm{x}$ & 2 & $\mathrm{p}$ & & & & $\mathrm{x}$ ih & $\mathrm{x}$ & & & 2 \\
\hline RR86-202 & 687755,5117349 & Meta-psammite & $\mathrm{x}$ & $\mathrm{x}$ & & $\mathrm{x}$ & 12 & $\mathrm{x}$ & $\mathrm{x}$ & & & $\mathrm{x}$ i m & & & & \\
\hline DM91-14 & 684371,5114745 & Meta-psammite & $\mathrm{x}$ & $\mathrm{x}$ & $\mathrm{x}$ & $\mathrm{x}$ & 1 & & $\mathrm{x}$ & & & $\mathrm{x}$ i m & & $\mathrm{x}$ & 2 & 2 \\
\hline DM91-32 & 686376,5115414 & Meta-psammite & $\mathrm{x}$ & $\mathrm{x}$ & $\mathrm{x}$ & $\mathrm{x}$ & 2 & $\mathrm{p}$ & & $\mathrm{x}$ & & $\mathrm{xi}$ & $\mathrm{x}$ & $\mathrm{x}$ & 2 & \\
\hline
\end{tabular}




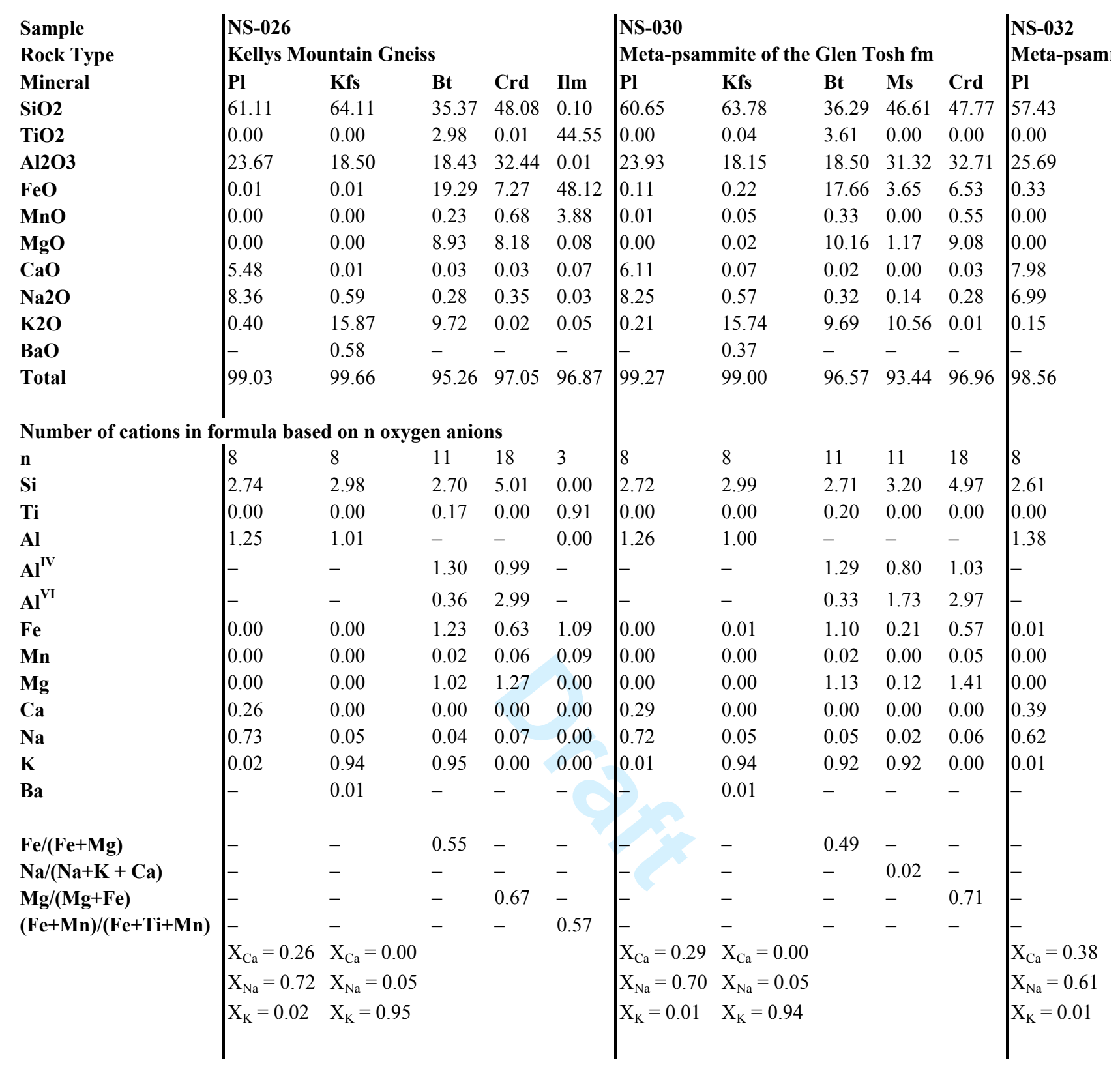




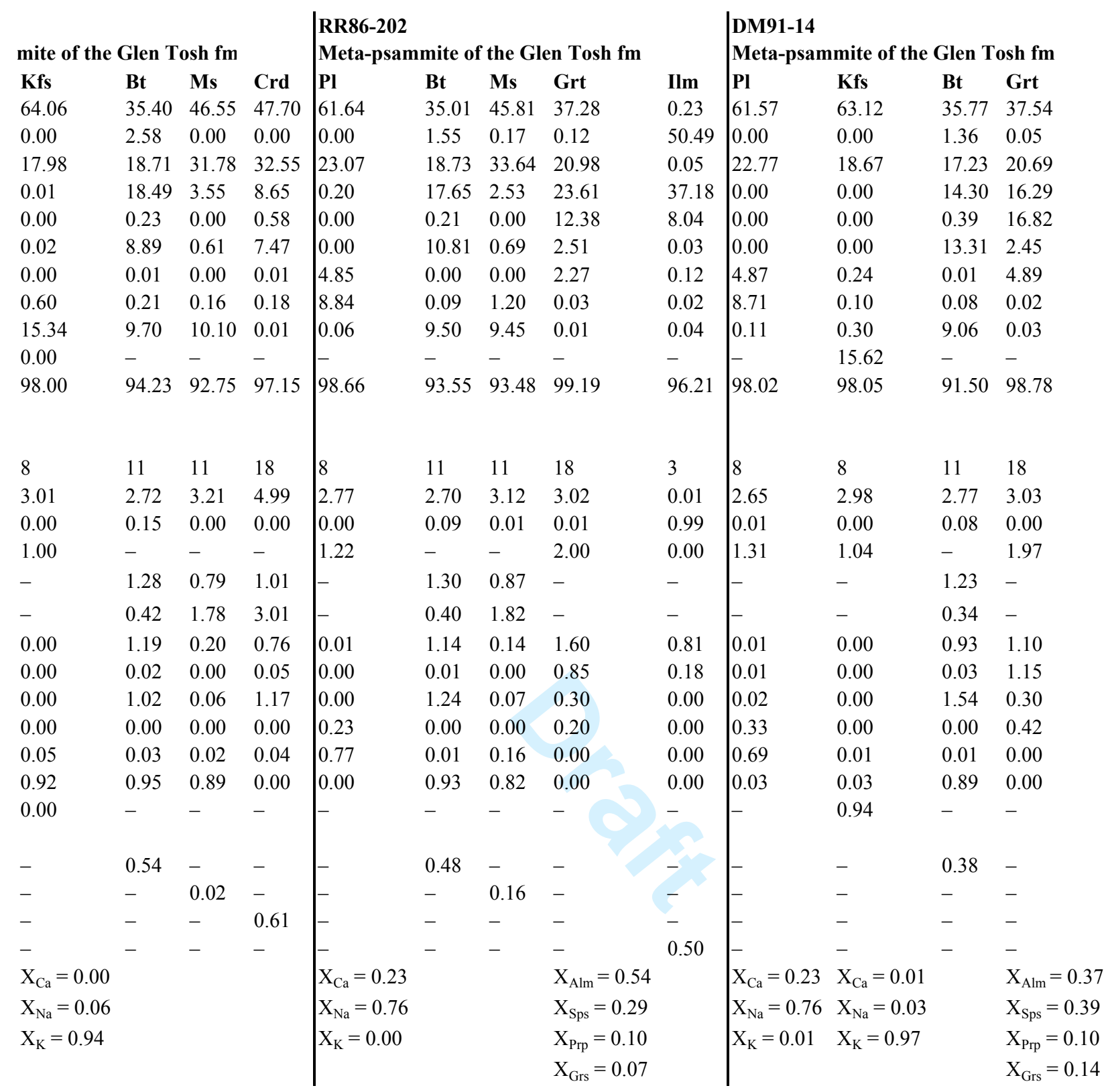




\begin{tabular}{|c|c|c|c|c|c|c|c|c|c|}
\hline \multirow{2}{*}{ Sample \# } & \multirow{2}{*}{ Analysis \# } & \multicolumn{4}{|c|}{ Approximate concentrations (ppm) } & \multirow{2}{*}{${ }^{204} \mathrm{PbCps}$} & \multirow{2}{*}{$2 \sigma$ int } & \multirow{2}{*}{$\begin{array}{c}{ }^{206} \mathrm{Pbcps} /{ }^{204} \\
\mathrm{PbCps}\end{array}$} & \multirow{2}{*}{$\% \mathrm{~Pb}^{*}$} \\
\hline & & Nd & $\mathbf{U}$ & Th & U/Th & & & & \\
\hline NS-030 & Mz-1 & 140700 & 863 & 55300 & 0.02 & 17 & 18 & 724 & 99.23 \\
\hline NS-030 & $\mathrm{Mz}-2^{*}$ & 710 & 14700 & 11800 & 1.25 & 15 & 16 & 150 & 99.97 \\
\hline NS-030 & $\mathrm{Mz}-3$ & 145500 & 2084 & 50000 & 0.04 & 19 & 19 & 1225 & 98.01 \\
\hline NS-030 & $\mathrm{Mz}-4$ & 136800 & 1043 & 53200 & 0.02 & -1 & 12 & -13120 & 98.98 \\
\hline NS-030 & Mz-5 & 132900 & 2940 & 45800 & 0.06 & 32 & 17 & 219 & 92.40 \\
\hline NS-030 & Mz-6a* & 5680 & 2639 & 2031 & 1.30 & -9 & 15 & -3403 & 99.61 \\
\hline NS-030 & Mz-6b* & 3770 & 13140 & 583 & 22.54 & 2 & 14 & 75500 & 99.96 \\
\hline NS-030 & Mz-7 & 143000 & 2967 & 54800 & 0.05 & 4 & 18 & 8535 & 98.97 \\
\hline NS-030 & Mz-9 & 138100 & 1213 & 65600 & 0.02 & 2 & 15 & 7485 & 99.06 \\
\hline NS-030 & Mz-12 & 131000 & 1560 & 43800 & 0.04 & -2 & 15 & -10100 & 98.68 \\
\hline
\end{tabular}




\begin{tabular}{|ccccccc|ccc}
\hline \multicolumn{9}{c}{ Final isotope ratios } & \multicolumn{3}{c}{ Ages (Ma) } \\
${ }^{207} \mathbf{P b} /{ }^{\mathbf{2 3 5}} \mathbf{U}$ & $\mathbf{2 \sigma}$ & ${ }^{\mathbf{2 0}} \mathbf{P b} /{ }^{\mathbf{2 3 8}} \mathbf{U}$ & $\mathbf{2 \sigma}$ & err. corr. & ${ }^{\mathbf{2 0 7}} \mathbf{P b} /{ }^{\mathbf{2 0 6}} \mathbf{P b}$ & $\mathbf{2 \sigma}$ & ${ }^{{ }^{207}} \mathbf{P b} /{ }^{\mathbf{2 3 5}} \mathbf{U}$ & $\mathbf{2 \sigma}$ & ${ }^{\mathbf{2 0 6}} \mathbf{P b} /{ }^{\mathbf{2 3 8}} \mathbf{U}$ \\
\hline 0.845 & 0.056 & 0.099 & 0.004 & 0.45 & 0.0607 & 0.0035 & 622 & 30 & 606 \\
1.080 & 0.140 & 0.130 & 0.006 & 0.31 & 0.0608 & 0.0074 & 752 & 64 & 790 \\
0.714 & 0.036 & 0.079 & 0.002 & 0.47 & 0.0649 & 0.0029 & 549 & 22 & 492 \\
0.705 & 0.030 & 0.087 & 0.002 & 0.28 & 0.0570 & 0.0022 & 539 & 18 & 538 \\
0.453 & 0.019 & 0.069 & 0.002 & 0.00 & 0.0470 & 0.0010 & 379 & 13 & 430 \\
$\mathbf{0 . 6 1 0}$ & $\mathbf{0 . 0 2 0}$ & $\mathbf{0 . 0 7 8}$ & $\mathbf{0 . 0 0 1}$ & $\mathbf{0 . 3 1}$ & $\mathbf{0 . 0 5 4 7}$ & $\mathbf{0 . 0 0 1 8}$ & $\mathbf{4 8 3}$ & $\mathbf{1 3}$ & $\mathbf{4 8 2}$ \\
$\mathbf{0 . 5 9 6}$ & $\mathbf{0 . 0 1 1}$ & $\mathbf{0 . 0 7 6}$ & $\mathbf{0 . 0 0 1}$ & $\mathbf{0 . 6 1}$ & $\mathbf{0 . 0 5 5 9}$ & $\mathbf{0 . 0 0 0 9}$ & $\mathbf{4 7 5}$ & $\mathbf{7}$ & $\mathbf{4 7 4}$ \\
$\mathbf{0 . 6 0 4}$ & $\mathbf{0 . 0 1 9}$ & $\mathbf{0 . 0 7 7}$ & $\mathbf{0 . 0 0 2}$ & $\mathbf{0 . 3 7}$ & $\mathbf{0 . 0 5 6 8}$ & $\mathbf{0 . 0 0 1 6}$ & $\mathbf{4 7 9}$ & $\mathbf{1 2}$ & $\mathbf{4 7 9}$ \\
$\mathbf{0 . 6 2 8}$ & $\mathbf{0 . 0 2 7}$ & $\mathbf{0 . 0 7 9}$ & $\mathbf{0 . 0 0 2}$ & $\mathbf{0 . 1 0}$ & $\mathbf{0 . 0 5 6 0}$ & $\mathbf{0 . 0 0 2 3}$ & $\mathbf{4 9 7}$ & $\mathbf{1 7}$ & $\mathbf{4 9 2}$ \\
0.696 & 0.032 & 0.086 & 0.002 & 0.24 & 0.0577 & 0.0027 & 537 & 19 & 530 \\
\hline
\end{tabular}




\begin{tabular}{cc|}
\hline $\mathbf{2 \sigma}$ & \% conc \\
\hline 22 & 97.4 \\
32 & 105.1 \\
10 & 89.6 \\
11 & 99.8 \\
14 & 113.5 \\
7 & $\mathbf{9 9 . 7}$ \\
$\mathbf{7}$ & $\mathbf{9 9 . 7}$ \\
$\mathbf{9}$ & $\mathbf{9 9 . 9}$ \\
$\mathbf{9}$ & $\mathbf{9 9 . 0}$ \\
10 & 98.8 \\
\hline
\end{tabular}

